\section{幽闹 Digital Commons@}

Loyola Marymount University

LMU Loyola Law School
Loyola of Los Angeles International and Comparative Law Review

6-1-2009

\title{
Jurisdiction to Prosecute Non-National Pirates Captured by Third States under Kenyan and International Law
}

James Thuo Gathii

Follow this and additional works at: https://digitalcommons.Imu.edu/ilr

Part of the Law Commons

\section{Recommended Citation}

James Thuo Gathii, Jurisdiction to Prosecute Non-National Pirates Captured by Third States under Kenyan and International Law, 31 Loy. L.A. Int'I \& Comp. L. Rev. 363 (2009).

Available at: https://digitalcommons.Imu.edu/ilr/vol31/iss3/2

This Article is brought to you for free and open access by the Law Reviews at Digital Commons @ Loyola Marymount University and Loyola Law School. It has been accepted for inclusion in Loyola of Los Angeles International and Comparative Law Review by an authorized administrator of Digital Commons@Loyola Marymount University and Loyola Law School. For more information, please contact digitalcommons@lmu.edu. 


\title{
Jurisdiction to Prosecute Non-National Pirates Captured By Third States Under Kenyan and International Law
}

\author{
JAMES THuO GATHII*
}

\section{INTRODUCTION}

In an undisclosed Memorandum of Understanding between Kenya and the United States signed on January 16, 2009, Kenya agreed to prosecute captured pirates in its courts. 'This was not the first time Kenya has agreed to such an arrangement. In a December 11, 2008, Memorandum of Understanding, Kenya agreed to receive and prosecute suspected pirates captured on the high seas by the United Kingdom. ${ }^{2}$ The British regarded Kenya as an alternative to trying suspects in Somalia, which the British argued had "no effective central government or legal system." Further, in March and August, 2009, Kenya signed similar agreements with the European Union and Denmark respectively, and others are reportedly planned with China and Canada.

\footnotetext{
*Associate Dean for Research and Scholarship and Governor George E. Pataki Professor of International Commercial Law, Albany Law School and Advocate of the High Court of Kenya. His book, WAR, COMMERCE AND INTERNATIONAL LAw, is forthcoming from Oxford University Press (2010).

1. David Morgan, Kenya Agrees to Prosecute U.S.-Held Pirates: Pentagon, REUTERS, Jan. 29, 2009, available at http://www.reuters.com/article/newsMaps/idUSTRE50S4ZZ20090129.

2. David Axe, Somali Pirates Face Justice, Finally, Wired, Dec. 15, 2008, http://blog.wired.com/defense/2008/12/pirates-have-th.html (last visited June 27, 2009).

3. Barney Jopson, Kenya Signs Deal to Prosecute Somali Pirates, FinanCIAL TimeS, Dec. 12, 2008.

4. Press Release, European Security and Defence Policy, Agreement with Kenya Signed (Mar. 6, 2009), available at http://www.consilium.europa.eu/uedocs/cms_data/docs/pressdata/en/esdp/106547.pdf. For the proposed China/Kenya Memorandum of Understanding on Prosecuting Pirates, see Claire Wanja, Kenya-China to Sign MOU on Anti-Piracy, KenYa BroadCasting CORPORATION, Mar. 4, 2009, available at http://www.kbc.co.ke/story.asp?ID=55949; A. Rienstra, Danish Navy Forges Deal With Kenya Over Somali Piracy, ICE NEws, Aug. 27,
} 
This Article examines Kenya's decision to receive and prosecute these suspects, as well as the important new Merchant Shipping Act of 2009, which confers on Kenyan courts jurisdiction over non-nationals for piratical acts committed extraterritorially. ${ }^{5}$ As a prelude, this article discusses previous piracy prosecutions in Kenya, followed by the structure and jurisdiction of Kenyan courts. The article then discusses the offense of piracy jure gentium in the Kenyan Penal Code, and the new offenses against hijacking and robbery by non-nationals on the high seas inaugurated by the new Merchant Shipping Act. ${ }^{6}$ The jurisdiction of Kenyan courts to undertake these prosecutions under both international and Kenyan law is analyzed. The article also considers the comity concerns as well as the competence of Kenyan courts to handle these prosecutions.

Based on the foregoing materials and analysis, this article concludes that the lack of a nexus between non-national pirates captured by third States in the high seas provides significant challenges to justifying universal jurisdiction over pirates in Kenya. This is especially so because Article 105 of the United Nation Convention on the Law of the Sea (UNCLOS) provides that jurisdiction over pirates belongs to the capturing State.' All the piracy suspects being tried in Kenya were captured by third States that then handed them over to Kenya for prosecution. To address this problem of lack of nexus over the piracy suspects, a new Merchant Shipping Act was enacted. This new law provides

2009, available at http://www.icenews.is/index.php/2009/08/27/danish-navy-forges-dealwith-kenya-over-somali-piracy. On the proposed China/Kenya Memorandum of Understanding on Prosecuting Pirates, see Claire Wanja, Kenya-China to Sign MOU on Piracy, KENYA BROADCASTING CORPORATION, Mar. 4, 2009, available at http://www.kbc.co.ke/story.asp?ID=55949 and Dan Lett, Canada Asks Kenya to Prosecute Pirates: MacKay, WINNIPEG FREe PRESS, May 21, 2009, available at http://www2.canada.com/topics/news/story.html?id=1617277.

5. The Merchant Shipping Bill, Part XVI (2008) (Kenya).

6. Id.

7. United Nations Convention on the Law of the Sea art. 105, Dec. 10, 1982, 1833 U.N.T.S. 396 [hereinafter UNCLOS]. For a full discussion, see infra notes 102-129 and accompanying text; see also DOUGLAS GUILFOYLE, SHIPPING INTERDICTION AND THE LAW OF THE SEA 40-41 (2009) (arguing that the UNCLOS "contains only a duty to suppress piracy on the high seas, it does not expressly provide for, as in the many of many terrorism suppression treaties, state prosecution of offenders discovered within their territorial jurisdiction for acts committed elsewhere ...."). Article 107 of the UNCLOS provides that a "seizure on account of piracy may be carried out only by warships or military aircraft, or other ships or aircraft clearly marked and identifiable as being on government service and authorized to that effect." UNCLOS supra, art. 107. 
extremely extensive jurisdiction over piracy by non-nationals in the high seas even when those suspected were captured by States other than Kenya. This new law also repealed the offense of piracy in Kenya's Penal Code. ${ }^{8}$

That said, several possible challenges to the broad extraterritorial scope over non-nationals created by this law under international law are also noted. This article then touches briefly on some of the international humanitarian and human rights issues that are posed by the increasing militarization of the multinational anti-piracy mission off the coast of Somalia. In conclusion, only limited prosecutions are feasible in Kenya, as the Kenya-U.S. Memorandum of Understanding of January 2009 suggests. In this sense, Kenya ought not become an off-shoring center for captured pirate suspects off the coast of Somalia, particularly in light of the congestion and related challenges in the country's criminal justice system.

\section{Previous Piracy Prosecution in Kenya ${ }^{9}$}

The first piracy trial in Kenya started in 2006 after the U.S. handed over to Kenyan authorities ten Somali nationals captured "approximately 200 miles off the coast of Somalia" by the guidedmissile destroyer, U.S.S. Winston Churchill. ${ }^{10}$ The pirates were charged before a Senior Principal Magistrate in Mombasa for hijacking the vessel MV Safina Al Bisaraat on the high seas on January 20, 2006, for threatening the lives of its crew and demanding a ransom ${ }^{11}$ in $R v$. Hassan M. Ahmed and 9 Others. ${ }^{12}$

8. Penal Code: Piracy, Revised Edition (2009) (2008) Cap. $63 \S 14$ (Kenya). Section 69 of the Penal Code was repealed by Merchant Shipping Act, (2009) Cap. $389 \S 454$ (1) (Kenya).

9. See Guled Mohamed, U.S.-Caught Somali Pirate Suspects Plead Innocence, REUTERS, Feb. 3, 2006, available at http://roa.redorbit.com/news/international/379116/uscaught_somali_pirate_suspects_plead_innoce nce/index.html.

10. Press Release, Embassy of the United States, Capture of Suspected Somali Pirates (Feb. 2, 2006), available at http://nairobi.usembassy.gov/pr_20060202.html. The signatories of the Memorandum were Kenya's Foreign Affairs Minister, Moses Wetangula, and British Security Minister, Lord West. The Memorandum "formalized an ad hoc arrangement" made between the Kenyan and British governments in November 2008. This agreement led to the initiation of the prosecution of eight pirate suspects arrested by the British while they allegedly tried to hijack a Danish cargo ship.

11. Id.

12. Judgment of Acting Senior Principle Magistrate B.T. Jagden dated November 1, 2006 in Rep. v. Hassan Mohamud Ahmed and 9 Others, (2006) Criminal Case No. 434 of 2006 (Chief Magis. Ct., Kenya) (on file with author). 
The accused were each sentenced to seven years in prison on October 26, 2006. ${ }^{13}$ The Court found no evidence that they were merely fishermen, or that any of them were minors, as had been alleged in their defense. ${ }^{14}$ Following the sentencing, an appeal arguing Kenyan courts lacked jurisdiction over the defendants over crimes committed by non-nationals on the high seas was filed. ${ }^{15}$ That appeal was rejected for reasons addressed in Part IV Section B below. ${ }^{16}$

There are several other ongoing piracy trials in which over one hundred suspected Somali pirates are charged before Kenyan Courts, following their seizure on the high seas by the combined military efforts of the European Union, the United States, and Denmark off the coast of Somalia and the subsequent transfer of these suspects to Kenyan custody for prosecution.

\section{TERRITORIAL JURISDICTION OF KENYAN COURTS}

Kenya has a three-tiered judicial system. The bottom tier consists of courts of first instance staffed by judicial officers with titles ranging from District Magistrate to Chief Magistrate. ${ }^{18}$

13. Kenya Jails 10 Somali Pirates for Seven Years, Reuters, Nov. 1, 2008, at http//www.alertnet.org/thenews/newsdesk/L011493396.htm.

14. Jail Sentence for Somali Pirates, BBC NEWS, Nov. 1, 2006, available at http://news.bbc.co.uk/2/hi/africa/6105262.stm.

15. Kenya Jails 10 Somali Pirates for Seven Years, supra note 13.

16. Hassan M. Ahmed v. Rep., (2009) Criminal Appeal Nos. 198, 199, 201, 203, 204, 205, 206 \& 207 of 2008 (High Court of Kenya) (decided on May 12, 2009 by Justice F. Azangalala J).

17. E.g., Eight Somali Piracy Suspects Charged in Kenya, CHINA ECONOMIC NeT, Nov. 20, 2008, available at http:/en.ce.cn/World/Africa/200811/20/t20081120_17439947.shtml. The suspects were captured on November 11, 2008, after attempting capture a Danish vessel, the $M V$ Powerful. They were charged on November 19, 2008. See Philip Muyanga, Ship Hit by Pirates Twice, Says Captain, DAILY NATION, Feb. 27, 2009, http://www.nation.co.ke/News/regional/-/1070/532038/-/71y5q6/-/index.html (reporting on the proceedings in the trial); see also Indonesian Pirates Sentenced for Sea Robbery in Malaysian Waters, CHANNELNEWSASIA.COM, June 14, 2005, excerpt available at http://www.easglespeak.us/2005/06/indonesian-pirates-sentenced-for-sea.html. For a full review of these ongoing cases, see James Gathii, Kenya's Piracy Prosecutions, 104 AM. J. INT'L L., (forthcoming Jan. 2010) (hereinafter Gathii, Kenya's Piracy Prosecutions) and James Gathii, "The Use of Force, Freedom of Commerce and Double Standards in Prosecuting of Pirates in Kenya," forthcoming American University Law Review (2010).

18. From top to bottom, the rank descends from Chief Magistrate, to Senior Principal Magistrate, to Principal Magistrate, to Senior Resident Magistrate, to Resident Magistrate, and finally to District Magistrate courts. The Chief Justice can enhance the pecuniary jurisdiction of each tier of these magistrates. Although the Civil Procedure Act $\S 15$ (2008) provides that suits shall be filed within the local limits of a court, the High 
Appeals of all criminal, civil, and customary law cases heard in subordinate courts go to the High Court of Kenya, the intermediate tier in Kenya's judicial system. The High Court may also call for review any case heard in the subordinate courts. The High Court also enjoys unlimited original jurisdiction over all cases in the country. Appeals on questions of law from the High Court go to the Court of Appeal, the highest court in the country. The Chief Justice sits on both the High Court and Court of Appeals. ${ }^{19}$

\section{EXTRATERRITORIAL CIVIL AND CRIMINAL JURISDICTION OF KENYAN COURTS}

The 2006 trial and conviction of pirates by a Senior Resident Magistrate found that, under Kenyan law, courts of first instance can assume jurisdiction over extraterritorial crimes committed by non-nationals. ${ }^{20}$ Such an extension of extraterritorial jurisdiction by courts of first instance, (also called subordinate courts in Kenya), however, does not have a sound legal basis, under Kenya's Penal Code. ${ }^{21}$

Court has held that the later rule contained in the Magistrates' Courts Act $\S 3(2)$, which provides that "[r]esident magistrate's Courts have jurisdiction throughout Kenya" prevails. Magistrates' Courts Act, (2007) Cap. 10, § 3(2). (Kenya); see Wekesa v. Otunga, [2005] eKLR (Kenya), available at http://www.kenyalaw.org/CaseSearch/case_download.php?go=14140078522995955338572 \&link=. Unlike Judges of the High Court and Court of Appeal, subordinate court magistrates do not enjoy the security of tenure under the Kenyan Constitution. These courts of first instance are often referred to as subordinate courts in Kenya.

19. Judgment of Acting Senior Principle Magistrate B.T. Jagden dated November 1, 2006 in Rep. v. Hassan Mohamud Ahmed and 9 Others, (2006) Criminal Case No. 434 of 2006 (Chief Magis. Ct., Kenya) (on file with author).

20. Kenya does not have a broad extraterritorial jurisdictional statute like the United States. See 18 U.S.C. $\S 7(7)$ (2006) (providing that the "special maritime and territorial jurisdiction of the United States, as used in this title, includes ... [a]ny place outside the jurisdiction of any nation with respect to an offence by or against a national of the United states."); see also United States v. Roberts, 1 F.Supp. 2d 601 (E.D. La. 1998) (asserting that under 18 U.S.C. $\S 7(7), \S(8)$, the Court has jurisdiction in a sexual abuse case involving non-U.S. citizens in the high seas).

21. While the Chief Justice of Kenya can use the Magistrates' Courts Act $\S 5(1)$ to enhance subordinate court jurisdiction, there is no legislative basis in Kenyan law that suggests the Chief Justice can confer extraterritorial jurisdiction to a subordinate court in the absence of a statutory grant of such a power to subordinate courts. This conclusion is supported by CONSTITUTION, Art. 76(1) (2008) (Kenya), which provides that "Parliament may establish courts subordinate to the High Court ... and a court so established shall have jurisdiction and powers as may be conferred on it by any law." It may be alternatively argued that subordinate courts have jurisdiction over extraterritorial piracy by non-nationals by virtue of the new Merchant Shipping Act. However, based on analysis 
By contrast, the High Court clearly has extraterritorial jurisdiction both as an admiralty court ${ }^{22}$ and, arguably, as a court of "unlimited original jurisdiction," for both criminal as well as civil cases as defined by the Constitution of Kenya. ${ }^{23}$ The High Court's admiralty jurisdiction is, however, only exercisable "in conformity with international law and the comity of nations." ${ }^{24}$ Therefore, civil claims may be brought in Kenya for recovery of losses arising from piratical attacks on the high seas. In fact, Kenyan courts have showed willingness in a recent case, though not deciding affirmatively, to extend the scope of the country's Marine Insurance $\mathrm{Act}^{25}$ extraterritorially to cover losses under an

of the respective jurisdiction of the High Court and subordinate courts, this would be an inaccurate statement. For example, $\S 5(1)$ of the High Court (Admiralty Rules) established under the Judicature Act authorizes subordinate courts to try suspected pirates by stating: "[t]he resident judge at Mombasa and every other judge before whom admiralty proceedings are pending may from time to time appoint a magistrate not below the rank of magistrate of the first class to be deputy marshal and the deputy marshal shall have in relation to those particular proceedings, subject to the direction of the judge, the power, authority, duties and functions of the Admiralty marshal." Available athttp:/www.kenyalaw.org/kenyalaw/klr_app/frames.php Even if this rule was read to confer jurisdiction on subordinate courts to try non-national pirates not captured by Kenya for piratical acts on the high seas, these rules are not themselves legislatively promulgated. As such, they do not form a legislative basis for extraterritorial jurisdiction for subordinate courts. A more direct reference of subordinate court jurisdiction over piracy is The Criminal Procedure Code, (2009) Cap. $75 \$ 4$ (Kenya), which provides that the "a subordinate court" may try offenses in the Penal Code. Furthermore, under the First Schedule of the Criminal Procedure Code, piracy jure gentium is triable by a "subordinate court of the first class presided over by a chief magistrate, senior principal magistrate, or a senior resident magistrate." It is uncertain whether the inclusion of piracy in this Schedule as triable in courts other than the High Court conclusively settles the jurisdiction over piracy by subordinate courts. Even if it does, the offenses created by the new Merchant Shipping Act are not, as of yet, similarly included in this schedule. Therefore, the jurisdiction of subordinate courts over non-national pirates for piratical acts committed on the high seas does not have conclusive support under Kenyan law.

22. The Judicature Act, (2007) Cap. 8 \& (1) (Kenya) provides that "[t]he High Court shall be a court of admiralty in matters arising in the high seas, or in territorial waters, or upon any lake or other navigable inland waters in Kenya." Similarly, the Merchant Shipping Act (2009) (Kenya) defines court as the "High Court exercising its admiralty jurisdiction." Finally, The Judicature Act $\S 4(2)$ provides that "[t] he admiralty jurisdiction of the High Court shall be exercisable - (a) over and in respect of the same persons, things and matters and (b) in the same manner and to the same extent, and (c) in accordance with the same procedure, as in the High Court of England, and shall be in conformity with international laws and the comity of nations."

23. CONSTITUTION, $\S 60(1)$ (2008) (Kenya) of the Kenyan Constitution states that "[t]here shall be a High Court, which shall be a superior court of record, and which shall have unlimited original jurisdiction in civil and criminal matters and such other jurisdiction -and powers as may be conferred on it by the Constitution or any other law."

24. The Judicature Act $\S 4(2)$ (c).

25. The Criminal Procedure Code $\S 4$. 
insurance policy for piracy outside Kenya's territorial waters. ${ }^{26}$ In that case, a defendant insurance company argued against being held liable for piratical acts that resulted in a covered loss because the UNCLOS defines piracy as conduct "directed against a ship, aircraft, persons, or property in a place outside the jurisdiction of any state." ${ }^{27}$ The Court rejected the defendant's argument, noting in part that there was "no reason to limit piracy to acts outside territorial waters, in the context of an insurance policy if a vessel was in the ordinary meaning of the phrase 'at sea' or if the attack upon her could be termed a maritime offense." 28

The Court in effect construed the terms "at sea" and "maritime offense" as capable of giving rise to insurance liability that arose in territorial waters as much as in the high seas. ${ }^{29}$ Of course, the extraterritorial application of a civil statute does not preclude non-Kenyan citizens brought before Kenyan courts to stand trial for alleged piratical acts outside of Kenya's territorial jurisdiction, to argue that Kenyan courts do not have personal jurisdiction over them because of the extraterritorial location of their acts ${ }^{30}$ or because they were captured by third States, which under Article 105 of the UNCLOS would have jurisdiction over them an issue discussed in Part B below.

26. Abdalla v. Corporate Ins. Co., [2005] eKLR (Kenya), available at http://www.kenyalaw.org/CaseSearch/case_download.php?go $=89006896419043610787262$ \&link=. Notably, in this case the parties agreed that the "vessel was operating within geographical limits set out in the policy.". However, the pirate attacks that resulted in the claim in this case occurred "in Somali waters near Kismayu." Ultimately, although the piracy was extraterritorial and the ship was registered in Tanzania, the court's jurisdiction was not in issue because the defendant, Corporate Insurance Co. Ltd - a private international company - had offices in Nairobi.

27. Id. at 6 (emphasis added).

28. Id. (citing with approval Athens Maritime Enters. Corp. v. Hellenic Mutual War Risks Ass'n (Bermuda) Ltd., [1983] Q.B. 647 (U.K.)).

29. Arguably, the Kenyan High Court in this context does not have to inquire if Parliament intended to make a specific statute to have extraterritorial effect. After all, the Judicature Act as well as the Merchant Shipping Act recognizes the High Court's admiralty jurisdiction. In the U.S., a clear statement by Congress of such extraterritorial intent is often required in the absence of an express stipulation by Congress that a statute should have extraterritorial effect. See Spector v. Norwegian Cruise Line Ltd., 545 U.S. 119 (2005).

30. Section 76(2) of the Criminal Procedure Code, while making the High Court the final and conclusive court to determine questions of doubt about its jurisdiction, nevertheless provides that "it shall be open to an accused person to show that no court in Kenya has jurisdiction in the case." The Criminal Procedure Code $\S 76(2)$. 


\section{A. Jurisdiction Over Extraterritorial Piracy: The High Court's Unlimited Original Clause}

The Constitution of Kenya grants the High Court expansive jurisdiction. The Constitution is the supreme law of the country and any law inconsistent with the Constitution is considered void. ${ }^{31}$ This grant of jurisdiction is the root of the Court's jurisdiction under Kenyan law. Section 60 of the Constitution terms this jurisdiction "unlimited original jurisdiction in civil and criminal matters." ${ }^{32}$ While this provision does not explicitly grant the High Court extraterritorial jurisdiction, the Constitution does not expressly limit the Court's jurisdiction to acts within Kenya's territory. ${ }^{33}$ The fact that the Constitution establishes the jurisdiction of the High Court with no reference to whether the civil or criminal acts that form the suits' subject matter occurred within Kenyan territory, strongly suggests that the Constitution confers upon the High Court a wide swath of power. Such jurisdiction includes extraterritorial jurisdiction, so long as it conforms to international law as required by the Judicature Act.

By contrast, with respect to courts of first instance, Section 3(2) of the Magistrates' Courts Act confers jurisdiction on them only "throughout Kenya." ${ }^{34}$ In short, Magistrates or subordinate courts in Kenya only have territorial jurisdiction. ${ }^{35}$ This is a major reason why prosecuting non-national pirates for acts outside Kenya in subordinate courts poses almost insurmountable jurisdictional barriers for sustaining such prosecutions in any Court in Kenya other than the High Court. Yet, Kenya is prosecuting non-national pirates captured on the high seas by third States in Magistrates' Courts, (or what we have referred to as courts of first instance or subordinate courts).

There is another reason that heavily leans against prosecution of piratical acts by non-Kenyan nationals outside Kenya's territorial jurisdiction in subordinate courts. The conferment of

31. CONSTITUTION, $\S 3$ (2008) (Kenya).

32. Id. at $\S 60$.

33. Id.

34. Magistrates' Courts Act $\S 3(2)$.

35. See Wekesa v. Otunga, [2005] eKLR (Kenya), available at http://www.kenyalaw.org/CaseSearch/case_download.php?go=14140078522995955338572 \&link $=$. 
jurisdiction in the High Court by the Constitution does not stop at the broad grant of "unlimited original jurisdiction." Rather, the Constitution further provides that the High Court shall have "such other jurisdiction and powers as may be conferred on it by this Constitution or any other law." 36

The clause "any other law" certainly includes the law of nations. ${ }^{37}$ This means that the High Court's jurisdiction over piratical acts outside Kenya by non-Kenyan nationals may arise from the law of nations or customary international law. Kenya's highest court, the Court of Appeals has held that "Kenya as a member of the international community subscribes to international customary laws and has ratified various international covenants and treaties." 38

The upshot of the argument, therefore, is that the High Court of Kenya has jurisdiction both under the Constitution and the Judicature Act to try persons for offenses against the law of nations. This is the most defensible legal basis for prosecuting nonnational pirates for extraterritorial piratical conduct in Kenyan courts. ${ }^{39}$ This position is further fortified by the fact that piracy jure gentium, and other crimes of an international character that are triable in domestic courts, cannot be directly created by customary or international law without a domestic statute conferring such jurisdiction. ${ }^{40}$ In short, it is not that customary international law

36. Constitution, $\$ 60$ (2008) (Kenya).

37. This is the case even though the Judicature Act, which defines sources of Kenyan law, does not enumerate international law as part of Kenyan law. I have, in fact, argued that International law, including the law of nations, is part of the law of Kenya. James Gathii, International Law as A Source of Kenyan Law (on file with the author).

38. Rono v. Rono, [2005] eKLR (Kenya), available at http:/www.kenyalaw.org/CaseSearch/case_download.php?go=66729264916840654106703 \&link =

39. For purposes of Kenyan law, therefore, non-Kenyan national piracy committed in the high seas falls within the criminal jurisdiction of the High Court in addition to murder and robbery with violence.

40. To argue that the law of nations directly establishes the crime of piracy for Kenya would be inconsistent with binding British precedent. R v. Keyn, [1876] 2 Exch. Div. 63, 203 (U.K.) (Cockburn, C. J. holding that "Nor, in my opinion, would the clearest unanimous assent on the part of other nations be sufficient to authorize the tribunals of this country to apply, without an Act of Parliament, what would practically amount to a new law. In so doing, we should be unjustifiably usurping the province of the legislature. The assent of nations is doubtless sufficient to give the power of parliamentary legislation in a matter otherwise within the sphere of international law; but it would be powerless to confer without such legislation a jurisdiction over foreigners in foreign ships on a portion of the high seas."). This holding was affirmed in R v. Bow Street Metro, Stipendiary Magistrate, [2000] 1 A.C. 147 (H.L.) (appeal taken from Q.B.) (U.K.) (holding that it was 
has directly created the triable offense of piracy in Kenyan courts, or that the Constitution has effectively assimilated the customary international law crime into Kenyan law. Rather, the Constitution of Kenya establishes a legal basis for the High Court's extraterritorial jurisdiction over non-nationals, and the power to prosecute such piracy is explicitly recognized in the Kenyan Penal Code. $^{41}$

\section{B. The Kenyan Penal Code Confers Jurisdiction Over Piracy Jure Gentium}

Although Kenya has no universal jurisdiction statute, its Penal Code criminalizes piracy in both Kenya's territorial waters and on the high seas. ${ }^{42}$ The Kenya Penal Code's definition of piracy as a crime within Kenya's territorial waters may be surprising given that piracy under international law is often understood as a crime committed on the high seas rather than in territorial waters or ports. ${ }^{43}$ In relevant part, the statute provides that "[a]ny person who, in territorial waters or upon the high seas, commits any act of piracy jure gentium is guilty of the offence of piracy." "4h This provision presumably creates universal jurisdiction, meaning that a pirate's contacts with Kenya are totally irrelevant when determining whether or not a Kenyan court has jurisdiction to prosecute the pirate. This view is also consistent with the outcome in the 1934 House of Lords decision, In re Piracy Jure Gentium, where the court held that "with regard to crimes as defined by international law, that law has no means of trying or punishing them. The recognition of international crimes as constituting domestic crimes, and the trial and punishment of

only after the coming into force of Section 134 of the Criminal Justice Act of 1998 that English criminal courts acquired jurisdiction over extra territorial torture).

41. The Penal Code, (2009) Cap. $63 \S 69$ (Kenya).

42. Id. ("(1) Any person who, in territorial waters or upon the high seas, commits any act of piracy jure gentium is guilty of the offence of piracy."); see also M. Cherif Bassiouni, Universal Jurisdiction for International Crimes: Historical Perspectives and Contemporary Practice, 42 VA. J. INT'L L. 81, 136-51 (2001) (arguing that universal jurisdiction over piracy is firmly established under international law and that it developed, in part, in the national laws and practices of major seafaring nations).

43. While UNCLOS II adopts the view that piracy is committed in the high seas, there are differing opinions and views on the traditional content of the international law of piracy, as well as the variety of approaches adopted by national laws on piracy. See BARRY HART DUBNER, THE LAW OF INTERNATIONAL SEA PIRACY, 38-39 (1990).

44. The Penal Code $\S 69(1)$. 
criminals are left to the municipal courts of each country." 45

Prosecution of piracy jure gentium would therefore be permissible since Kenya is a dualist country - rules of international law are binding as a matter of domestic law only when Parliament has passed legislation to implement international norms. ${ }^{46}$ While the Penal Code applies to crimes within Kenya ${ }^{47}$ it also applies to crimes committed partly within and partly outside of Kenya. ${ }^{48}$ While the Penal Code does not explicitly confer jurisdiction for crimes committed entirely outside of Kenya, the fact that it criminalizes piracy committed on the high seas, a crime recognized under the law of nations; may be argued to implicitly confer jurisdiction on the Kenyan High Court. Such an interpretation is supported by English precedents such as In re Piracy Jure Gentium, which Kenyan courts would consider persuasive authority on this question of first impression. ${ }^{49}$ The downside to prosecution of piracy jure gentium under the Penal Code is that it provides prosecutorial authorities with little domestic law guidance on what the elements of the crime of piracy jure gentium are. Suffice it to say, the crime of piracy jure gentium in the Kenyan Penal Code is a reflection of a similar prohibition in Article 101 of the UNCLOS, ${ }^{50}$ which Kenya ratified on March 23, 1989. ${ }^{51}$ In fact, in Rep. v. Hassan

45. In Re Piracy Jure Gentium, [1934] A.C. 586 (P.C. 1934) (U.K.); see also United States v. Hudson \& Goodwin, 11 U.S. 32, 34 (1812) (holding that a person cannot be tried for an international crime in the United States unless Congress adopts a statute).

46. In R.M. v. Attorney Gen., the High Court went even further noting even where a treaty had been ratified but not domesticated with an implementing legislation. R.M. v. Attorney Gen., [2006] eKLR (Kenya), available at http://www.kenyalaw.org/CaseSearch/case_download.php?go=62792276441650128565711 \&link $=$. Nevertheless, the Court could take a treaty into account when interpreting an ambiguous provision of a statute.

47. See The Kenya Penal Code $\S 5$ ("The jurisdiction of the courts of Kenya for the purposes of this Code extends to every place within Kenya, including territorial waters.").

48. See id. at $\S 6$ ("When an act which, if wholly done within the jurisdiction of the court, would be an offence against this Code, is done partly within and partly beyond the jurisdiction, every person who within the jurisdiction does or makes any part of such act may be tried and punished under this Code.in the same manner as if such act had been done wholly within the jurisdiction.").

49. See generally In re Piracy, [1934] A.C. 586.

50. The Secretary-General, Follow-Up to the Implementation of the World Summit for Social Development and of the Twenty-Fourth Special Session of the General Assembly, U.N. Doc. A/62/122 (July 11, 2007).

51. UNCLOS, supra note 7, art. 101.

Piracy is defined as any of the following acts: (a) any illegal acts of violence or detention, or any act of depredation, committed for private ends by the crew or passengers of a private ship or a private aircraft, and directed: (i) on the high seas, against another ship or aircraft, or against persons or property on board 
Mohamud Ahmed, a Magistrate"s Court, and subsequently on appeal to the High Court, Article 101 of the UNCLOS was cited to justify the assumption of jurisdiction over Somali pirates captured in the high seas by U.S. naval forces. Remarkably, the reliance on Article 101 in this case was for more than simply the definition of piracy. The High Court used Article 101 of the UNCLOS as a legal justification for jurisdiction of Kenyan courts over non-nationals who committed the offence extra-territorially and that had been captured by foreign forces. Next I will discuss those decisions and how they used Article 101 of the UNCLOS rather than Article 105 to justify jurisdiction over piracy in Kenya.

In Rep. v. Hassan Mohamud Ahmed, the Magistrate's Court in response to the argument that Kenyan courts had no jurisdiction over piracy, the Court noted and held that:

The defence submissions...fail to demonstrate how the codification of the International Customary Law under UNCLOS ousts the provisions of S. 69 of the Penal Code which provided to [sic] the offence of Piracy jure gentium. It appears to me that UNCLOS amplifies what is already provided for under the panel [sic] code for the offence fo [sic] piracy. Section 69(1) of the Penal Code refers to both territorial waters and the high seas. Section 2 of the Penal Code is a [sic] in respect of an act done beyond the ordinary jurisdiction of the Kenyan courts. I therefore agree with the prosecution that any act of piracy jure gentium is a crime against mankind which lies beyond the protection of any State. ${ }^{52}$ Jure gentium asper Block [sic] Law dictionary 8th Edition meant 'By the law of Nations"'. It is a

such ship or aircraft; (ii) against a ship, aircraft, persons or property in a place outside the jurisdiction of any State; (b) any act of voluntary participation in the operation of a ship or of an aircraft with knowledge of facts making it a pirate ship or aircraft (c) any act of inciting or of intentionally facilitating an act described in subparagraph (a) or (b).

Id. For the date of Kenya's ratification, see United Nations, Oceans and Law of the Sea, available

http://www.un.org/Depts/los/reference_files/chronological_lists_of_ratifications.htm\#The $\% 20$ United $\% 20$ Nations $\% 20$ Convention $\% 20$ on $\% 20$ the $\% 20$ Law $\% 20$ of $\% 20$ the $\% 20$ Sea.

52. The prosecution had argued that "there is universal jurisdiction irrespective of where the crime occurs or the nationality of the person committing it. That it's a crime against mankind which lies beyond the protection of any state ...." Judgment of Acting Senior Principle Magistrate B.T. Jagden dated November 1, 2006 in Rep. v. Hassan Mohamud Ahmed and 9 Others, (2006) Criminal Case No. 434 of 2006 (Chief Magis. Ct., Kenya) (on file with author). 
crime with international dimensions. Piratical acts include violence, detention acts that cause harm or damage etc. Article 101 of UNCLOS defines piracy as consisting of the afore stated acts. $^{53}$

Just to emphasize, it is notable that in this extract of the Magistrate's Court's judgment referred to Article 101 of the UNCLOS which defines piracy, rather than Article 105 which provides that any State may seize pirates on the high seas or outside its jurisdiction and its courts may take any action against the pirates so seized and their vessel and property. ${ }^{54}$ Although Article 105 makes jurisdiction more readily available, perhaps the Magistrate's Court and the government in presenting its case to the Court realized that Article 105 presented an insurmountable difficulty. That is, the pirates charged before Kenyan courts were captured by other States that could more readily rely on Article 105 than Kenya could. ${ }^{55}$ In fact for this reason, one commentator has already alluded to the fact that these Kenya prosecutions are arguably illegal under Article 105 of the LOS Convention. ${ }^{56}$ As shown so far, that view is entirely accurate.

After the conviction and sentence each of the suspects to seven years imprisonment, ${ }^{57}$ the appeal that was filed in the High Court did not raise lack of jurisdiction based on Article 105 of the UNCLOS - that since Kenya did not arrest any of the suspects,

53. Id. at 154-155.

54. "On the high seas, or in any other place outside the jurisdiction of any State, every State may seize a pirate ship or aircraft, or a ship or aircraft taken by piracy and under the control of pirates, and arrest the persons and seize the property on board. The courts of the State which carried out the seizure may decide upon the penalties to be imposed, and may also determine the action to be taken with regard to the ships, aircraft or property, subject to the rights of third parties acting in good faith . ..." UNCLOS, supra note 7, Art. 105.

55. Notably, another basis upon which Kenya could have assumed jurisdiction was under a Kenya-U.S. shiprider agreement, under which U.S. vessels policing piracy off the coast of Somalia would transfer captured pirates to Kenyan arresting officers. On this, see James Kraska \& Brian Wilson, Fighting Piracy: International Coordination is Key to Countering Modern-Day Freebooters, ARMED FORCES J., Feb. 2009, http://www.armedforcesjournal.com/2009/02/3928962 (noting that "the U.K. signed a counterpiracy cooperation agreement with Kenya in December [2008], agreeing to transfer captured pirates to Mombasa for prosecution[,]" and "[t]he U.S. and Kenya concluded a similar arrangement on Jan. 29[, 2009].").

56. Eugene Kontorovich, International Decisions: United States v. Shi, 103 AM. J. INT'L L. 739 (Oct. 2009).

57. Jail Sentence for Somali Pirates, supra note 14. 
Article 105 jurisdiction was unavailable. ${ }^{58}$ Instead, the appeal to the High Court contested the jurisdiction of the Principal Magistrate's Court on the grounds that the accused persons were non-Kenyans and that the acts of piracy they had been convicted of in the lower court were committed outside Kenya. ${ }^{59}$ Just as in the trial in the lower court, the government argued that it did not matter where the crimes had been committed or who had committed them since as the lower court had held, piracy was "a crime against mankind which lies beyond the protection of any state." ${ }^{60}$ The High Court, as well as the lower court, must have intended to mean that the crime of piracy was punishable by any state, rather than beyond the protection of any state. ${ }^{61}$ The High Court noted that the provisions of Section 69(1) of the Penal Code which until it was repealed by the Merchant Shipping Act provided that 'any person' on the 'high seas' could be found guilty of the offence of piracy were broad enough to cover the prosecution of non-national suspects captured 300 kilometers off the Somali coast on international waters. ${ }^{62}$ The High Court further buttressed its holding by referring to another. statute, the Kenyan Criminal Procedure Code. According to the High Court, the fact that the first schedule of that Statute grants jurisdiction to

58. Kenya's Criminal Procedure Code provides for appeals from convictions from Magistrates' Courts. Magistrates' Court Act, $\$ 10$; see Hassan M. Ahmed v. Rep., (2009) Criminal Appeal Nos. 198, 199, 201, 203, 204, 205, 206 \& 207 of 2008 (High Court of Kenya) (decided on May 12, 2009 by Justice F. Azangalala J).

59. Hassan M. Ahmed v. Rep., supra note 16,The other grounds of appeal related to alleged inadequacies in the evaluation and reliance on the evidence presented to the lower court as the basis for their conviction, the dismissal of their defense and the imposition of an excessive punishment. Id. at 2. Notably, Section 76(2) of the Criminal Procedure Code, while making the High Court the final and conclusive court to determine questions of doubt about its jurisdiction, nevertheless provides that "it shall be open to an accused person to show that no court in Kenya has jurisdiction in the case." The Criminal Procedure Code $\$ 76(2)$.

60. Hassan M. Ahmed v. Rep., supra note 16, at 5.

61. This, and other grammatical and spelling errors in the judgment, particularly in the Principal Magistrates' Court opinion, are perhaps a reflection of the fact that proceedings are recorded in long hand by the Magistrate or Judge and then typed by a Typist or Secretary who has no legal training. Since June 2008, Kenyan courts have been working on expanding digital recording and transcription of court records. Peter Mwaura, Kenya: Electronic Recording of Cases Will Certainly Speed up Justice, DAILY NATION, June 14, 2008, available at http://allafrica.com/stories/200806160071.html. See also Kenya Law Reports, About the National Council for Law Reporting, http://www.kenyalaw.org/about/index.php?content=7 (last visited Jan. 25, 2010) (noting that the National Council for Law Reporting "is pioneering a project for the digital recording and transcription of court proceedings.").

62. See Hassan M. Ahmed v. Rep., supra note 16, at 9. 
Magistrates' Courts in Kenya to try such cases. ${ }^{63}$ For this reason the High Court concluded that the ground of appeal based 'on want of jurisdiction must fail. ${ }^{64}$ The High Court in effect argued that if jurisdiction was unavailable under the aforementioned Kenyan Statutes, it was available under the UNCLOS:

... I must hold that the learned Principal Magistrate was bound to apply the provisions of the Convention [UNCLOS] should there have been deficiencies in our Penal Code and Criminal Procedure Code. I would go further and hold that even if the Convention had not been ratified and domesticated, the Learned Principle Magistrate was bound to apply international law and norms since Kenya is a member of the civilized world and is not expected to act in contradiction to expectations of member states of the United Nations. ${ }^{65}$

Quite significantly, the High Court noted that even if the Magistrate had no jurisdiction, such jurisdiction would be available under Article 101 of the UNCLOS, whether or not Kenya had domesticated the UNCLOS. ${ }^{66}$ This holding by the High Court, while consistent with recent decisions in which the High Court and Court of Appeal have applied ratified but undomesticated treaties

63. Id. at 10. Such reasoning on the basis of a schedule to a statute is very doubtful since a schedule to a statute can hardly be regarded as capable of overriding the express terms of a statute..

64. Hassan M. Ahmed v. Rep., supra note 16, at 12.

65. Id. at 10-11 (emphasis added). To fortify its decision, the High Court cited MARTIN DIXON, INTERNATIONAL LAW (2007) (although the court did not cite to which edition of the book it was citing) for the proposition that "Under international Law, there are certain crimes which are regarded as so destructive of the international order that any state may exercise jurisdiction in respect of them. This is jurisdiction which exists irrespective of where the act constituting the crimes takes place and the nationality of the person committing it. . . . It seems clear that piracy, war crimes and crimes against humanity (e.g. genocide) are crimes susceptible to universal jurisdiction under customary international law... . The universal principle of jurisdiction rests then, on the nature of the 'crime' committed rather than the perpetrator of the place of commission." Id. at 11 .

66. Id. at 10. On behalf of the State it was inaccurately argued both before the Principal Magistrate and the High Court that Kenya had domesticated the UNCLOS. While Kenya ratified the UNCLOS in 1989, it was not until June 1, 2009 when the Merchant Shipping Act of 2009 was signed into law that that treaty was domesticated in Kenya. The High Court noted that neither in the lower court nor on appeal "was a contrary view ... given by counsel for the appellants," that the UNCLOS had been domesticated. Id. This observation by the High Court gives further credence to my argument that piracy has occasioned a decisive break with dualism even though the reasoning of the High Court and the lower court finding jurisdiction over non-national pirates captured outside Kenya leaves much room for doubt. 
to resolve ambiguities or gaps in domestic statutes, ${ }^{67}$ is nonetheless broader than those decisions for at least two reasons. First, previous decisions that have used ratified treaties that are not domesticated or norms of customary international law have largely been as an additional backdrop against which statutory interpretation was undertaken. In the piracy context, a treaty provision is used to establish universal jurisdiction over piracy as an independent basis for the existence of jurisdiction over nonKenyan nationals charged with committing offenses in the high seas. Thus, Article 101 of the UNCLOS, rather than domestic law is invoked not simply to fill a statutory gap or to help in interpreting a statute. Instead, Article 101 of the UNCLOS was invoked for a more far-reaching purpose - as a legal justification establishing the piracy jurisdiction of Kenyan courts over nonnationals who committed the offence extra-territorially and that had been captured by foreign forces.

Thus, arguably under the High Court's reasoning, universal jurisdiction over genocide committed extra-territorially by nonKenyan nationals arrested by forces of another country outside Kenya would fall within the jurisdiction of Kenyan courts on the reasoning that there was an expectation that such jurisdiction would be available since Kenya is a member of the civilized world and of the United Nations. As I note below, such a proposition is hardly accepted by any country that I am aware of at the moment.

While some jurists agree that no territorial or nationality nexus is necessary for a State exercise jurisdiction over piracy, ${ }^{68}$ this view is neither reflected in State practice or existing treaty law. ${ }^{69}$ The Kenyan example is made all the more exceptional since

67. For example, in Rono $v$. Rono the court of appeals noted, "As a member of the international community, Kenya subscribes to international customary laws and has ratified various international covenants and treaties." Rono v. Rono, [2005] eKLR (Kenya), available

http://www.kenyalaw.org/CaseSearch/case_download.php?go=66729264916840654106703 \&link =. If some of these treaties had not been domesticated, they had to be taken into account in resolving the central question of discrimination if that were in issue in that case. Id. at 10 .

68. See, e.g., M. Cherif Bassiouni, Accountability for International Crime and Serious Violations of Fundamental Human Rights: International Crimes: Jus Cogens and Obligations Erga Omnes, 59 LAw \& CONTEMP. PROBS. 63, 65 (1996).

69. See, e.g., Kenneth C. Randall, Universal Jurisdiction: National Courts and the Prosecution of Serious Crimes Under International Law, 99 AM. J. INT'L L. 293, 793 (2005) 
no implementing legislation permitting the exercise of such jurisdiction exists for any of the piracy trials currently being tried in Kenya. ${ }^{70}$ Exercises of universal jurisdiction by States without territorial or nationality links to those charged have in the recent past raised doubts about propriety of its exercise ${ }^{71}$ and there have been extremely few such cases. ${ }^{72}$ This is particularly so given that States whose militaries have captured those pirates eventually brought to Kenya have a more direct relationship to the suspects and indeed have a right to exercise jurisdiction over them under Article 105 of UNLCOS. ${ }^{73}$ That many of these States have decided not to prosecute these pirates strongly suggests Article 105 of the UNCLOS merely confers discretion, and it does not establish a

(book review) (arguing that "Piracy's mere occurrence on the high seas thus does not alone subject the offense to universal jurisdiction"); Bartram S. Brown, The Evolving Concept of Universal Jurisdiction, 35 NEW ENG. L. REV. 383, 392-393 (2001). Bartram S. Brown, The Evolving Concept of Universal Jurisdiction, 35 NEW. ENG. L. REV. 383, 392-93 (2001).

70. The High Court and Principal Magistrates' Court in Rep. v. Hassan Mohamud Ahmed, construed Section 69 of the Penal Code as constituting such national action taken pursuant to a customary international law prohibition as noted above. Judgment of Acting Senior Principle Magistrate B.T. Jagden dated November 1, 2006 in Rep. v. Hassan Mohamud Ahmed and 9 Others, (2006) Criminal Case No. 434 of 2006 (Chief Magis. Ct., Kenya) (on file with author). Even if one accepts such a construction of the Penal Code as implementing a customary international law offence, the question of obtaining jurisdiction over non-nationals for offences in the high seas in Kenya and captured by foreign forces is a very broad construction, given the nexus required for the exercise of such jurisdiction under Article 105 of the UNCLOS. Notably, Principle 3 of Princeton's Principles of Universal Jurisdiction adopts the view that "national judicial organs may rely on universal jurisdiction even if their national legislation does not specifically provide for it." STEPHEN MACEDO ET AL., THE PRINCETON PRINCIPLES ON UNIVERSAL JURISDICTION princ. 3, at 30 (2001).

71. A perhaps dramatic example is the exercise of universal jurisdiction by Belgium over Israeli and U.S. governmental and military officials for allegedly committing war crimes in the occupied territories, and in Iraq, respectively. Belgium eventually amended its universal jurisdiction statute to reach only those individuals with links to Belgium. See Malvina Halberstam, Belgium's Universal Jurisdiction Law: Vindication of International Justice or Pursuit of Politics, 25 CARDOZO L. REV. 247, 266 (2003) (arguing that universal jurisdiction statutes "must make provision[s] to prevent misuse ... for political purposes."). But see Lama Abu-Odeh, A Radical Rejection of Universal Jurisdiction, 116 YALE L.J. POCKET PART 393 (2007), http:/www.thepocketpart.org/images/pdfs/555.pdf (arguing that universal jurisdiction is far less likely to be available with reference to crimes committed by "rich and powerful states").

72. The Eichman Case is one of the few examples. Attorney-General of the Government of Israel v. Eichmann, 36 I.L.R. 5 (S. Ct. Isr. 1961), affd, 36 I.L.R. 277 (S. Ct. Isr. 1962); see also, Randall, supra note 69, at 296.

73. In addition, the flag States of the vessels subjected to piratical attacks and the States of the nationals involved in those attacks have a greater interest in engaging in prosecutions of these pirates than Kenya does. 
mandatory requirement that capturing states must exercise jurisdiction over piracy. ${ }^{74}$ If this is so, Kenya's decision to prosecute Somali pirates captured by other States is grounded on as much a purist interpretation of universal jurisdiction ${ }^{75}$ as much as in self interest. ${ }^{76}$

In short, while the Kenyan High Court has validated jurisdiction over piracy for the ongoing piracy prosecutions, its decision fails to convincingly show how Article 101 of the UNCLOS provided jurisdiction over non-Kenyan suspects captured on the high seas by foreign forces

74. To avoid the problems of prosecutions, many States capturing these pirates have engaged in release and capture. However, on March 10, 2009, when German marines captured suspected Somali pirates who were attacking a German-owned shipping line flying an Antiguan flag and captained by a Filipino, the German government decided with elections coming up that "[t]he average German won't understand why Somalis captured in international waters should be tried at German taxpayers' expense," in addition to the fact that the captives might seek asylum in Germany. Diana Fong, Politics Influences the Jurisdiction for Somali Pirate Trials, DEUTSCHE WELLE Apr. 22, 2009, http://www.dwworld.de/dw/article/ $0,4198300,00$.html. (quoting Oliver Wallasch, a Frankfurt lawyer who is representing one of the seized pirates in German courts alleging inhumane treatment in Kenya). Instead, Germany detained the suspects while the European Union hurriedly negotiated an agreement with Kenya to prosecute the pirates. See id.

75. M. Cherif Bassiouni, The History of Universal Jurisdiction and Its Place in International Law, in UNIVERSAL JURISDICTION: NATIONAL COURTS AND THE PROSECUTION OF SERIOUS CRIMES UNDER INTERNATIONAL LAW 39, 65 (Stephen Macedo ed., 2004). A non-purist position would be that for crimes erga omnes, such as piracy and slavery, with respect to which a State has no territorial or national nexus, there is an option rather than a mandate to prosecute. See Lori F. Damrosch, Comment: Connecting the Threads in the Fabric of International Law, in UNIVERSAL JURISDICTION: NATIONAL COURTS AND THE PROSECUTION OF SERIOUS CRIMES UNDER INTERNATIONAL LAW 91, 94 (Stephen Macedo ed., 2004).

76. The self-interest here being all the assistance promised to Kenya to address daunting problems in its judiciary in return for trying the pirates. See Mike Corder, Nations Look to Kenya as Venue for Piracy Trials, Associated PRess, Apr. 17, 2009, available

http://www.law.com/jsp/law/international/LawArticleIntl.jsp?id=1202429986132 (quoting Mark Ellis, executive director of the International Bar Association, as saying "Kenya has a number of challenges it is facing as a country and particularly as they affect the judicial system [and] ... I don't think the hurdles are insurmountable, but it will take a much more structured and aggressive approach by the international community to assist Kenya in undertaking this type of trial."). 


\section{Future Prosecutions Under Kenya's New Merchant SHIPPING LAW}

The tenuousness of jurisdiction exercised to prosecute piracy in Kenya and the lack of guidance on the elements of the crime of piracy in the Penal Code noted above will, in future cases, no longer be an issue. This is because the Kenyan Parliament recently passed the Merchant Shipping Act. The act incorporates piracy jure gentium, as well as the new offenses of robbery and hijacking ships, all of which cover both the high seas and Kenya's territorial waters. Notably, suspects already captured for piratical acts prior to the President signing the law into effect are only prosecutable for the crime of piracy jure gentium under the Penal Code, as seen above. ${ }^{77}$ The reason is straightforward - like in many countries, ex post facto crimes are prohibited in Kenya. ${ }^{78}$ Therefore, prosecutions under the new Merchant Shipping Act may only be based on crimes committed after the law took effect.

That law, the Merchant Shipping Act ${ }^{79}$ of 2009, was passed by the Kenyan Parliament on February 12, 2009. President Kibaki subsequently signed it into law on May 29, 2009 and it came into effect on 1st September, 2009. ${ }^{80}$ The new law replaced the 1967 Merchant Shipping Act and bring Kenya into compliance with a variety of international maritime conventions. The new law also partly incorporates a variety of provisions of the UNCLOS and the 1988 Convention for the Suppression of Unlawful Acts Against the Safety of Maritime Navigation ("SUA Convention"). ${ }^{81}$ Thus,

77. Constitution, $§ 77(4)$ (1998) (Kenya).

78. Id. ("No person shall be held to be guilty of a criminal offence on account of an act or omission that did not, at the time it took place, constitute such an offence, and no penalty shall be imposed for such a criminal offence that is severer in degree or description than the maximum penalty that might have been imposed for that offence at the time when it was committed.").

79. Merchant Shipping Act (2009) (Kenya).

80. Kibaki Signs Shipping Bill Into Law, DAILY NATION, May 31, 2009, available at http://www.nation.co.ke/News/politics/-/1064/605188/-/xy08ppz/-/.

81. Convention for the Suppression of Unlawful Acts Against the Safety of Maritime Navigation, Mar. 10, 1988, 1678 U.N.T.S. 221 [hereinafter SUA Convention]. Kenya has also ratified the SUA Convention Protocol. See International Maritime Organization (IMO), Status of Conventions By Country (Apr. 30, 2009), available at http://www.imo.org/TCD/mainframe.asp?topic_id=248. Among the other treaties, the new law seeks to domesticate the International Convention for the Safety of Life at Sea and its Protocols of 1978 and 1988. International Convention for the Safety of Life at Sea, Nov. 1, 1974, 32 U.S.T. 47. This new Kenyan law is part of a major overhaul of the Maritime Sector in Kenya. The Authority was initially established in subsidiary in 2004. See Order 
under both domestic and international law, Kenya has undoubtedly expressed its concern regarding threats to the safety and security of passengers, crews, and ships on the high seas.

Section 368 of the Merchant Shipping Act adopts the definition of piracy contained in Article 101 of the UNCLOS. ${ }^{82}$ Additionally, Section 370 of the new law adopts the offenses contained in Article 3 of the SUA Convention regarding hijacking and destroying ships, with some minor modifications. ${ }^{83}$ To address non-Kenyan pirate suspects operating extraterritorially, Section 370(4) provides that these offenses shall apply "whether the ship... is in Kenya or elsewhere," whether the offenses were "committed in Kenya or elsewhere," and "whatever the nationality of the person committing the act." Merchant Shipping law confers upon Kenyan courts wider jurisdiction than that provided by the SUA Convention.

Legal Notice No. 70, Ken. Mar. Auth. (2004). In 2006, the Kenyan Parliament passed the Kenya Maritime Authority Act, which established the Kenya Maritime Authority run by a Director General, a Registrar of Ships, a Registrar of Seafarers, a Principal Receiver of Wreck, and a Principal Surveyor of Ships. These long overdue reforms represented very successful lobbying by interest groups in the maritime industry. The passage of the Merchant Shipping Act was given impetus by the need to establish a framework for prosecuting pirates off the coast of Somalia. In addition to lobbying in Kenya by groups such as the Seafarers Assistance Program, the International Maritime Organization encouraged Kenya to pass the new law so that it could "qualify for the 'White List' of countries deemed to be properly fulfilling their obligations under the 1978 International Convention on Standards for Training, Certification, and Watchkeeping for Seafarers (STCW)." Efthimios E. Mitropoulos, Sec'y Gen. Int'l Mar. Org., Remarks at the Meeting with H.E. Hon. Mwai Kibaki, President of the Republic of Kenya in Nairobi (May 4, 2006), available

http://www.imo.org/About/mainframe.asp?topic_id=1322\&doc_id=6315.

82. Merchant Shipping Act art. 370 (2009) (Kenya); UNCLOS, supra note 7, art. 101.

83. Merchant Shipping Act art. 370 (2009) (Kenya) ("[s]ubject to subsection (5), a person who unlawfully, by use of force or by threats of any kind, seizes a ship or exercises control of it commits the offence of hijacking a ship. (2) Subject to subsection (5), a person commits an offence if he unlawfully and intentionally (a) destroys a ship; (b) damages a ship or its cargo as to endanger, or to be likely to endanger, the safe navigation of a ship; (c) commits, on board a ship, an act of violence which is likely to endanger the safe navigation of the ship; or (d) places or causes to be placed on a ship any device or substance which is likely to destroy the ship or is likely so to damage it or its cargo as to endanger is safe navigation. (3) Nothing in subsection (2)(d) is to be construed as limiting the circumstances in which the commission of any act may constitute (a) an offence under subsection (2)(a), (b) or (c); or (b) attempting or conspiring to commit, or aiding, abetting, counseling, procuring or inciting, or being of and part in, the commission of such an offence."); SUA Convention, supra note 81, art. 5 (providing that "[e]ach State Party shall make the offences set forth in article 3 punishable by appropriate penalties which take into account the grave nature of these offences.").

84. Merchant Shipping Act art. 370 (2008) (Kenya). 
Article 6 of the SUA Convention provides that States establish jurisdiction through having a nexus with the offense. ${ }^{85}$ This includes offenses: committed on their flag ships; ${ }^{86}$ in their territory $;{ }^{87}$ by their nationals; ${ }^{88}$ by stateless persons whose habitual residence is in that State; ${ }^{89}$ when a national of the state is injured, threatened or killed in the course of the commission of the offense $;{ }^{90}$ and when the offense is "committed in an attempt to compel that State to do or abstain from doing something." Moreover, Article 6(4) of the SUA Convention further confirms that territoriality or a strong nexus to a State is the predicate necessary to establishing jurisdiction. ${ }^{92}$ In fact, this is the manner in which other SUA Convention States have crafted their implementing legislation. For example, in the United States the implementing legislation closely follows the SUA Convention jurisdictional provisions $^{93}$ and, unlike Kenya's Merchant Shipping Act, provides no explicit extraterritorial jurisdiction where there are no direct links with the U.S. ${ }^{94}$

Under Kenya's Merchant Shipping Act, the penalty for hijacking or destroying a ship is life imprisonment. ${ }^{95}$ Section 372 criminalizes endangering the safe navigation of any ship and makes the offense punishable whether it is "committed in Kenya or elsewhere :... whatever the nationality of the person committing the act." ${ }^{96}$ Unlike the crime of piracy jure gentium, which is now

85. SUA Convention, supra note 81 , art. 6 .

86. Id. art. $6(1)(\mathrm{a})$.

87. Id. art. $6(1)(\mathrm{b})$.

88. Id. art. $6(1)(\mathrm{c})$.

89. Id. art. $6(2)(\mathrm{a})$.

90. Id. art. $6(2)(\mathrm{b})$.

91. Id. art. $6(2)(\mathrm{c})$.

92. Id. art. 6(4).

93. See 18 U.S.C.A. $\$ 2280$ (2006).

94. See United States v. Shi, 525 F.3d 709, 723 (9th Cir. 2008) (noting in part that the U.S.'s implementing legislation "expressly provides foreign offenders with notice that their conduct will be prosecuted by any state signatory."). As noted below, U.S. courts are likely to exercise broad extraterritorial jurisdiction on other grounds, including where extraterritorial conduct is "purposefully aimed at the United States." See United States v. Aikens, 946 F.2d 608, 613-14 (9th Cir. 1990). Note of course the U.S. is prosecuting the lone pirate suspect who survived a naval rescue of the US flag and captained Maersk Alabama. See Criminal Complaint, United States v. Abduwali Abdukhadir Muse, No. 1:09-mj-01012-UA (S.D.N.Y. Apr. 21,2009), terminated and re-filed by Criminal Indictment, United States v. Abduwali Abdukhadir Muse 1:09-cr-00512-LAP (S.D.N.Y. May 19, 2009)

95. Merchant Shipping Act art. 371 (2008) (Kenya).

96. Id. art. 372 . The penalty for this type of offense is a fine "not exceeding ten 
repealed, the new shipping law elaborates the specific elements that constitute the crimes of hijacking or destroying a ship, thereby giving prosecutorial authorities invaluable guidance. ${ }^{97}$ The statute also provides that the master of a ship has an obligation to deliver to Kenyan authorities, or to any SUA Convention country, a person they reasonably believe to have committed any of the foregoing offenses. ${ }^{98}$

The Merchant Shipping Act provides that prosecutions for offenses defined in it may, "without prejudice to the provisions of any other law relating to prosecutions, be conducted by any officer appointed under" the new law, and "specially authorized in writing in that behalf by the Attorney-General." 99 This provision does not, however, appear to remove from the regular Kenyan judicial system the prosecution of piracy or robbery of ships. ${ }^{100}$ Rather, this provision seems to relate to the myriad of other maritime related civil offenses created under this new law. ${ }^{101}$

million [Kenyan] shillings" or "imprisonment not exceeding ten years." Id. art. 420.

97. For example, the law defines "act of violence" as any done in or outside Kenya if "it constitutes the offence of murder, attempted murder, manslaughter, or assault." Id. art. 370(7). Similarly, it defines "unlawfully," whether committed in or outside Kenya, as meaning "an offense under the law of Kenya." Id. This guidance is crucial given the various definitions of piracy contained in different Conventions. In addition to the definition of piracy in the UNCLOS, which applies to piracy in the high seas and in exclusive economic zones, there is the definition of piracy in Article 15 of the 1958 Convention on the High Seas as well as that contained in Article 2 of the International Maritime Committee's Model National Law. See Convention on the High Seas art. 15, Apr. 29, 1958, 450 U.N.T.S. 82; see also Comité Maritime International, Model National Law on Acts of Piracy and Maritime Violence, art. 2 (2001), available at http://www.comitemaritime.org/singapore2/singafter/modelgen/modelgen2.html. Notably, the International Maritime Bureau defines "piracy" to includes attacks against ships "in the territorial sea or archipelagic waters of a state," while the International Maritime Organization defines the crime of "armed robbery against ships" as including crimes committed within a "State's jurisdiction." See Robert C. Beckman, Combatting Piracy and Armed Robbery Against Ships in Southeast Asia: The Way Forward, 33 OCEAN DEV. \& INT'L L. 317, 319-20 (2002).

98. Merchant Shipping Act art. 373 (2008) (Kenya).

99. Id. art. 428.

100. Id. art. 430(3) (jurisdiction shall not be "in addition to, and not in derogation of, any jurisdiction or power of the court under any other law."). In addition, the new law establishes jurisdiction over Kenyans and non-Kenyans who commit offenses on board a Kenyan ship, whether on the high seas, in any foreign port, or on board any foreign ship in Kenya to which he or she does not belong. Id. art. 432. This law further provides that offenses or complaints made under it shall be "deemed to have been committed in any place in Kenya," wherever the offender and person complaining "may be for the time being," for the purpose of establishing jurisdiction over them. In the Kenyan judicial system, the Admiralty Judge is any judge of the High Court of Kenya sitting in Mombasa.

101. Id. art. 420 . This provision establishes an offense for failure to comply with an 


\section{THE NEW LAW's EXTRATERRITORIAL JURISDICTION AND UNCLOS}

Article 105 of the UNCLOS provides that " $[t]$ he courts of the State which carried out the seizure [of pirates] may decide upon the penalties to be imposed, and may also determine the action to be taken with regard to the ships, aircraft, or property, subject to the rights of third persons acting in good faith." ${ }^{102}$ It has been suggested that, as a matter of customary international law, this provision gives jurisdiction to prosecute pirates solely to capturing States. ${ }^{103}$ Here, it is important to remember the authoritative study of the law of piracy undertaken by Alfred P. Rubin. Rubin noted that Article 105 of the UNCLOS was lifted from Article 18 of the International Law Commission's Law of the Sea Codification of 1958. ${ }^{104}$ According to Rubin, Article 105 of the UNCLOS illustrated "the way in which the Commission resolved the conflict between 'naturalist' jurists who view 'piracy' as a crime against international law seeking only a tribunal with jurisdiction to apply that law and punish the criminal, and 'positivist' jurists who view 'piracy' as solely a municipal law crime, the only question of international law being the extent of a state's jurisdiction to apply its criminal law to an accused foreigner acting outside the territorial jurisdiction of the prescribing state." 105

Article 18 of the International Law Commission's Law of the Sea Codification of 1958 was adopted in Article 105 of the UNCLOS as a compromise. ${ }^{106}$ It defined piracy as an international crime, thereby adopting a positive rule, while leaving its enforcement to domestic law, as naturalists would have had it. ${ }^{107}$ In so doing, the UNCLOS, like the text of the Harvard Research Draft Convention on Piracy, was de lege ferende (or an instance of

improvement notice issued by an inspector to a ship owner, master, or member of a ship crew who is in violation of any provision of the statute. This law further provides that offenses or complaints made under it shall be "deemed to have been committed in any place in Kenya" wherever the offender and person complaining "may be for the time being" for the purpose of establishing jurisdiction over them. Id. art. 430.

102. UNCLOS, supra note 7, art. 105.

103. Eugene Kontorovich, International Legal Responses to Piracy off the Coast of Somalia, 13(2) AM. SOC'Y INT'L L.: INSIGHT, Feb 6 2009, available at http://www.asil.org/insights090206.cfm.

104. Alfred P. Rubin, The Law of Piracy 360 (2d ed. 1988).

105. Id.

106. Id.

107. Id. 
progressive codification), rather than established customary international law. ${ }^{108}$ Recent reference to Article 105 of the UNCLOS has sought to establish where jurisdiction for prosecution of suspected pirates seized in the high seas lies. However, what has often gone unnoticed is the expansive "enforcement jurisdiction" meant to seize not only pirates, but also "any pirate ship or aircraft" and "any property on board" - a view consistent with the view that naval powers have "a special authority to safeguard international commerce based on the[ir] special interest, military strength and moral assertiveness." Given the inconsistency in States' practice regarding norms defining jurisdiction over piracy, it is unclear how much weight a domestic tribunal prosecuting pirates ought to place on, for instance, the definition of piracy in Article 101 of the UNCLOS, especially if there is no mirror domestic law. This view is consistent with Alfred Rubin's argument that:

[T] here is no international law of 'piracy' at all, and it is possible that there never has been any such law except in the autointerpretive projections of some states from time to time seeking either to expand their jurisdiction to safeguard their own trade or establish imperial interests, or in theories of those who prefer to call their personal moral insights as 'law' as if universally applicable and not requiring legislative decision by a 'legislator' empowered within a legal order.

Returning to the question of jurisdiction over suspected pirates captured in the high seas, the few contemporary cases of prosecution of pirates seem to confirm the accuracy of Alfred Rubin's argument about the mixed legacy of natural and positive

108. Id. at 340-41 (concluding that "the Harvard draft must be evaluated on its own merits as a legislative proposal, and cannot be supported as a reflection of a scholarly analysis of precedent and theory," and also stating that "the Harvard researchers thus did not necessarily diminish the value of their proposal as an exercise de lege ferenda.").

109. Id. at 318. According to Rubin, "'piracy' with regard to foreign officials remained as it existed in the nearly nineteenth century ... a pejorative applied to non-European and unrecognized rebel military forces to which the statesmen wished to attach a sense of illegality under international law .... The failures in practice to encourage non-European societies to conform their behavior to the needs of European commerce by calling their military arms, or even their governments, 'piratical,' appears not to have been noticed by statesmen, who persisted in using the word 'piracy' and its derivatives to refer generally to illegality under international law, but in the ultimate moment in every known case either to withdraw from that usage, withhold the legal results that they had argued should flow from it, or to apply the law of war to conflicts that ensued." Id. at 314.

110. Id. at 343 . 
law in the law of piracy. ${ }^{111}$ These contemporary examples show that while piracy continues to be universally condemned, consistent with the views of naturalists, jurisdiction over their prosecution continues to be defined by national legislation, as positivists preferred. Examples in line with Article 105 of the UNCLOS include reports that the government of Somaliland ${ }^{112}$ has on more than one occasion arrested and prosecuted pirates. ${ }^{113}$ There is also the example of Somali pirates, captured on the high seas by the French Navy in April 2008 for holding a French yacht hostage, who are still in the custody of French authorities facing possible prosecution. ${ }^{114}$

Then there are contrary examples where the capturing State handed over suspected pirates to another State. For example, as mentioned above, in 2006, the United Kingdom turned over Somali pirates to Kenya for prosecution. Furthermore, Danish authorities have now surrendered to the Netherlands five Somali pirates captured in the Gulf of Aden by the Danish Navy in early January 2009. ${ }^{115}$ Finally, on March 5, 2009, the United States

111. For a recent empirical study showing the extremely low number of piracy prosecutions relative to arrests, see Eugene Kontorovich \& Steven Art, The Limits of Judicial Altruism: An Empirical Examination of Universal Jurisdiction for Piracy (Northwestern Univ. Pub. L. \& Legal Theory, Research Paper No. 09-26; Northwestern Univ. L. \& Econ., Research Paper No. 90-45, Dec. 6, 2009), available at http://www.ssrn.com/abstract $=1519518$.

112. Somaliland became independent from British colonial rule in June 1960 but joined the Italian administered UN Trusteeship of Southern Somaliland, which eventually became the Somali Republic. However, after civil war broke out in Somalia in 1991, Somaliland declared it had seceded from the Somali Republic. Somaliland maintains more effective control over its territory than Somalia, which is governed by the Transitional Federal Government. Somaliland is currently seeking membership in the African Union as a State separate from Somalia. See INTERNATIONAL CRISIS GROUP, AFRICA REPORT No. 110, SOMAlILAND: TIME FOR AFRICAN UNION LEADERSHIP (2006). The government of Somaliland has offered its ports for international anti-piracy operations. See Andrew Cawthorne \& David Clarke, Somaliland Offers Ports for Anti-Pirate Operations, REUTERS, Dec. 4, 2008, available at http://www.alertnet.org/thenews/newsdesk/L4451910.htm.

113. See, e.g., Five Somali Pirates Given Each 12 Years Prison Terms by Somaliland Government, SOMALILAND PRESS, Dec. 22, 2008, available at http://somalilandpress.com/526/five-somali-pirates-given-each-12-years-prison-terms-bysomaliland-government/.

114. Un Navire de Guerre Français Déjoue une Attaque de Pirates Somaliens, LE MONDE (Fr.), Jan. 2, 2009.

115. Dutch Urge Closer EU Cooperation to Combat Piracy, AFP, Jan. 16, 2009, available at http://www.expatica.com/nl/news/european_news/Dutch-urge-closer-EUcooperation-to-combat-piracy_48731.html. It is reported the pirates would be tried under article 381 of the Dutch Criminal Code, which outlaws piracy. Id. It would be the first time 
handed over to Kenya seven suspected pirates, captured by the United States in February 2009. ${ }^{116}$ These suspects were among the first to be tried under the January 2009 U.S./Kenya MOU for piracy. ${ }^{117}$ In addition, there are several other cases underway in Kenya before the Mombasa Chief Magistrates' Courts where suspected Somali pirates are charged following their seizure on the high seas by various foreign militaries who were subsequently surrendered to Kenya. ${ }^{118}$

While these examples are certainly not intended to be exhaustive, they strongly suggest the continuing relevance and applicability of traditional rules of jurisdiction. These include those based on the nationality of the victims, ship, or aircraft, and those based on the originating or destination countries of the cargo in the vessel subjected to piratical attack. ${ }^{119}$

Kenya's new maritime law does not avoid the questions of jurisdiction and standing over non-national piratical acts and robbery on the high seas. As discussed above, it does so by explicitly defining the crimes of robbery and attacks on vessels on the high seas as crimes under Kenyan law notwithstanding the nationality or location of the crimes. Kenya's new maritime law follows the SUA Convention's model of criminalizing acts of violence against vessels on the high seas, particularly Article 9.

for such a prosecution, and the pirates may, if convicted, be sentenced up to 12 years in prison. Id. In the incident in which the Danish navy captured the suspected pirates, flares were fired at the vessel, setting it on fire and causing the suspects to jump into the water. See also Pirates Handed Over to Dutch Authorities, The COPENHAGEN POST, Feb 10, 2009, available at http://www.cphpost.dk/news/international/89-international/44705pirates-handed-over-to-dutch-authorities.html.

116. David Morgan, U.S. Delivers Seven Somali Pirate Suspects to Kenya, ReUTERS, Mar. 5, 2009, available at http://www.reuters.com/article/idUSTRE52480N20090305. In addition, on March 10, 2009, the German Navy handed over nine Somalis to Kenyan authorities for trial in Kenya. See German Navy Hands Somali Pirates to Kenya - Police, AFP, Mar. 10, 2009, available at http://forexdaily.org.ru/Dow_Jones/page.htm?id=486777.

117. See Sarah Childress, Pact with Kenya on Piracy Trials Gets First Test, WALL ST. J., Feb. 17, 2009, available at http://online.wsj.com/article/SB123482019865794481.html. For more on these prosecutions, see Gathii, Kenya's Piracy Prosecutions, supra note 17. .

118. Eight Somali Piracy Suspects Charged in Kenya, supra note 17. The suspects were charged on November 19, 2008. Id. They had been captured on November 11, 2008, when they attempted to capture a Danish vessel, $M V$ Powerful. See also Muyanga, supra note 17 (reporting on the proceedings in the trial). For an earlier case, see also Indonesian Pirates Sentenced for Sea Robbery in Malaysian Waters, supra note 17.

119. Cf. RUBIN, supra note 104 at 360 (noting that the approach in the ILC's Draft articles "avoids all considerations of 'standing,' the legal link between the incident or the accused or his victim on the one side, and the state seeking to extend its jurisdiction on the other."). 
Article 9 provides that the Convention does not "affect in any way the rules of international law pertaining to the competence of States to exercise investigative or enforcement jurisdiction on board ships not flying their flag." 120 A very elastic interpretation of this clause could be argued as acknowledging the existence of the traditional bases of jurisdiction to prescribe in circumstances other than those relating to States that capture suspected pirates.

For example, a state may exercise jurisdiction under the passive personality principle to prosecute suspected pirates who have injured or killed a person of their nationality, or who destroyed or robbed that person's property even if such conduct occurred in the high seas. ${ }^{121}$ While in the past the United States was reluctant to assert extraterritorial criminal jurisdiction over non-U.S. nationals, the U.S. Congress has since expanded the extraterritorial reach of its statutes over non-nationals to protect U.S. nationals. ${ }^{122}$ Indeed, rules of jurisdiction often require the state that is exercising jurisdiction to prescribe some connection between the prescribing state and either the nationality of the perpetrator or victim of an extraterritorial crime, or the effects of

120. SUA Convention art. 9 , supra note 81,1678 U.N.T.S. at 289 . Indeed, the last two paragraphs of the preamble to the SUA Convention provide that "matters not regulated by this Convention continue to be governed by rules and principles of general international law" and that "all States, in combating unlawful acts against the safety of maritime navigation, [must] strictly . . comply with rules and principles of general international law." Id.

121. For example, in United States v. Yunis, 924 F.2d 1086, 1091 (D.C. Cir. 1991), the United States Court of Appeals for the District of Columbia held that "a state may punish non-nationals for crimes committed against its nationals outside its territory, at least where the state has a particularly strong interest in the crime." See also United States v. Yousef, 927 F. Supp. 673, (S.D.N.Y. 1996) (upholding extraterritorial jurisdiction over a non-national for conspiring to bomb an aircraft extraterritorially - in the Philippines); United States v. Bin Laden, 92 F. Supp. 2d 189, 221 (S.D.N.Y. 2000) (relying on passive personality principle as "increasingly accepted as applied to terrorist and other organized attacks on a state's nationals by reason of their nationality" (citing RESTATEMENT (THIRD) OF FOREIGN RELATIONS LAW § $402 \mathrm{cmt}$ g (1987))); United States v. Pizdrint, 983 F. Supp. 1110, (M.D. Fla. 1997) (finding that the court had jurisdiction based on the principle of the effects doctrine in a case involving the assault and battery of an American by a non-U.S. citizen aboard a Liberian vessel on the high seas because the vessel engaged in substantial business within the United States and regularly operated in U.S. territory).

122. Joshua Robinson, Note, United States Practice Penalizing International Terrorists Needlessly Undercuts Its Opposition to the Passive Personality Principle, 16 B.U. INT'L L.J. 487, 497-504 (1998); see also Abraham Abramovsky, Extraterritorial Jurisdiction: The United States Unwarranted Attempt to Alter International Law in United States v. Yunis, 15 YALE J. INT'L L. 121 (1990) (arguing that expanding the territorial reach of jurisdiction over non-U.S. nationals was not justified under either domestic or international law). 
such a crime. ${ }^{123}$

Like the United States' experience in extending jurisdiction through the passive personality principle, Kenya's new Merchant Shipping law appears to expand the country's extraterritorial jurisdiction over high seas shipping crimes beyond those involving non-Kenyan nationals or interests. Recall, the new law applies to the offenses of hijacking and robbery of ships irrespective of whether the ship is in Kenyan waters or elsewhere, and irrespective of the nationality of the person committing the act. For this reason, the prosecution of these crimes may be contested as too broad an expansion of Kenya's extraterritorial jurisdiction to prescribe where the offenses alleged have only a remote connection to Kenya. ${ }^{12}$

The best case Kenya could make to defend its broad new extraterritorial reach over non-nationals for piratical attacks on the high seas captured by third countries is the practice of the English Courts. Kenya's Judicature Act explicitly authorizes the High Court in exercise of its admiralty jurisdiction to adopt the same jurisdiction "as in the High Court in England." ${ }^{125}$ While the British Merchant Shipping Act of 1995 confers only territorial jurisdiction on British courts for offenses such as pollution, ${ }^{126}$

123. Arrest Warrant of Apr. 11, 2000 (Dem. Rep. Congo v. Belg.), 2002 I.C.J. 121 9l 1517 (Feb. 14) (separate opinion of Judge Guillame). In the Arrest Warrant case, President Guillame noted that "[i]n classic international law, [States] normally have jurisdiction in respect of an offense committed abroad only if the offender, or at very least the victim, is of their nationality, or if the crime threatens its internal or external security." Id. II 16.

124. Kenya could, of course, argue that it has a broad interest in the safety of shipping routes on the Indian Ocean coast to counter such an argument in cases with a remote connection to Kenya. In the Sexual Offences Act of 2006, the Kenyan Parliament provided for extraterritorial jurisdiction over Kenyan citizens and permanent residents of Kenya if an act that "would constitute a sexual offence had it been committed in Kenya" is committed outside Kenya. The Sexual Offences Act, No. 52 (2006), KENYA GAZETTE SUPPLEMENT NO. $97 \S 41$. This example is much more limited than that embodied in the new Merchant Shipping law.

125. The Judicature Act $\S 4(2)(c)$. The High Court of Kenya has confirmed this position in a number of cases. E.g., E. African Power Mgmt. Ltd. v. Owners of the Vessel "Victoria Eight" [2005] eKLR 1-2 (Kenya), available at http://www.kenyalaw.org/CaseSearch/case_download.php?go=85860709219590573846503 \&link = (holding that the Kenyan High Court entertains admiralty matters in the same manner as the High Court of England under the United Kingdom's Supreme Court Act of 1981).

126. 43 HALSBURY'S LAWS OF ENGLAND ch. 2, I 1189 (4th ed. 1997) (restriction over offenses outside United Kingdom limits); see also Merchant Shipping and Maritime Security Act, 1997, C. $28, \S 26(2)$ (U.K.) (defining the high seas as including "all waters beyond the territorial sea of the United Kingdom"). 
piracy committed in the high seas does not limit the admiralty jurisdiction of British courts in a similar manner. ${ }^{127} \mathrm{It}$ is, therefore, not accidental that a recent change in the High Court of Kenya website alludes to piracy on the high seas as falling within the Court's admiralty jurisdiction. ${ }^{128}$

Before leaving the question of jurisdiction to prescribe, it may be apposite to note that the recent U.S./Kenya and EU/Kenya MOUs, under which Kenya would prosecute captured pirates in the high seas, arguably establish jurisdiction by agreement. This kind of jurisdiction is often used to establish jurisdiction over nonnational forces on foreign territory. ${ }^{129}$ In some jurisdictions, treaties with 'extradite or prosecute' provisions have been interpreted as establishing jurisdictional agreements among the contracting parties to extradite or prosecute offenders. ${ }^{130}$ Such an agreement has recently been suggested to defend jurisdiction over a non-national in the high seas in the case of a one-ship piracy, ${ }^{131}$ even when such a defendant is brought within a court's jurisdiction involuntarily. ${ }^{132}$

127. 11 HALSBURY's LAWS OF ENGLAND, supra note 126, III 625 ("Acts done on, or by means of, a foreign ship on the high seas, but outside the territorial waters of the United Kingdom, are not within the Admiralty jurisdiction if done by a foreigner, except in the case of piracy jure gentium ...."), 634 ("Other offences committed abroad for which aliens as well as British subjects may be tried in England include piracy jure gentium."); Id. If 735 ("The English courts have jurisdiction to try all cases of piracy jure gentium in whatever part of the high seas and upon whosoever's property it may be committed, and whether the accused are British subjects or the subjects of any foreign state with whom Her Majesty is at amity.").

128. Judiciary Structure - The High Court, Republic of Kenya, http://www.judiciary.go.ke/about/structure_content.php?content=1.

129. See LORI F. DAMROSCH ET AL., INTERNATIONAL LAW: CASES AND MATERIALS 1143-55 (4th ed. 2001).

130. United States v. Yousef, 327 F.3d 56, 96 (2d Cir. 2003).

131. United States v. Shi, 525 F.3d 709, 720-724 (9th Cir. 2008).

132. Id. at 725 (holding that jurisdiction was proper because physical location in the United States need not have been voluntary and the SUA "contains no such voluntary entry requirement"). Section 2280(b)(1)(C) of 18 U.S.C. confers jurisdiction on a U.S. Court where the "offender is later found in the United States after such activity is committed." There is no similar provision in the SUA Convention. Likewise, there is no provision in the SUA Convention authorizing jurisdiction over non-nationals for extraterritorial crimes as there is in the Kenyan legislation. See SUA Convention, supra note 81, 1678 U.N.T.S. 221; The Merchant Shipping Bill, Part XVI, II 368 (2008) (Kenya); see also United States v. Postal, 589 F.2d 862, 873 (5th Cir. 1979) (holding that there is ample authority that "a mere violation of a law not embodied in a treaty binding the United States" does not oust the jurisdiction of a U.S. Court and that "a defendant may not ordinarily assert the illegality of his obtention to defeat the court's jurisdiction over him"). 
Could it then be that jurisdiction to prescribe for crimes of international law has been reconfigured from norms providing "which state can exercise authority over whom, and in what circumstances' to norms that establish under what conditions the international community ... may prescribe international rules of conduct?" "133 In short, is universal jurisdiction over widely condemned conduct such as piracy and slavery the norm today? While this argument has support in customary international law, without a domestic statute that establishes jurisdiction over extraterritorial conduct with little nexus to a country, jurisdictional difficulties to prosecute remain. ${ }^{134}$ Kenya may certainly be able to show its interests in the safety of commercial shipping and the delivery of humanitarian assistance through the Gulf of Aden and the Indian Ocean. Its interests, however, may not be any more superior to those of other nations when the commerce is not destined for, or expected to pass through, Kenya. In any event, the extraterritorial jurisdiction over non-nationals in Kenya's new Merchant Shipping Act exceeds the bases for jurisdiction in the SUA Convention. As -such, the strongest base for Kenya's jurisdiction over non-national piratical acts in the high seas is its own laws and the choices it will make to prosecute such cases. So far, it is reported that the U.S./Kenya Memorandum of Understanding is not a wholesale acceptance to prosecute all suspects captured in the high seas. Rather, Kenya has agreed to selectively prosecute a limited number of such pirates. ${ }^{135}$ As Kenya's Minister of Foreign Affairs Moses Wetangula noted, the MOU was not "an open door for dumping pirates onto Kenya[n] soil because it will not be acceptable."

133. Leila Nadya Sadat, Redefining Universal Jurisdiction, 35. NEW ENG. L. REV. 241, 245 (2001) (quoting Rosalyn Higgins, Problems AND Process: InTERnational LAW AND HOW WE USE IT 56 (1994)) (emphasis omitted).

134. This requirement of nexus or effects in Kenya is strongly suggested by the High Court of Kenya decision in Musisi v. Republic, where it held that an offense committed outside Kenya by a Kenyan fell within the jurisdiction of the High Court because "the appellant's fraud[, though committed abroad,] was to get the Kenya government to act upon it in Kenya." Musisi v. Republic, 48 Int'l L. Rep. 90, 91 (Feb. 21, 1969).

135. Childress, supra note 117 (noting that under the MOU, Kenya "has agreed to take only a limited number of cases" and that "the [Kenyan] government would decide which cases to try in part based on where the alleged crimes took place. [And further that] Kenya has provided the [U.S.] Navy with a checklist of evidence required to prosecute . . . .").

136. Kenyan Foreign Minister Shed Light on U.S.-Kenya Piracy Agreement, THE TURKISH WEEKLY, Jan. 28, 2009, available at 


\section{COMITY CONCERNS OF THE EXTRATERRITORIAL REACH OF THE NEW LAW AND RECENT SC RESOLUTIONS}

The extraterritorial extension of one country's criminal laws and sanctions, as opposed to civil laws, raises special concerns under international law. ${ }^{137}$ International law limits the extraterritorial extension of a State's criminal laws. ${ }^{138}$ In this sense, Kenya is adopting very broad constructions of its jurisdiction to prescribe; much like the United States has done by its oftenaggressive enforcement of both the criminal and civil penalties of its antitrust laws. ${ }^{139}$ While Somalia arguably has a 'clearly greater ${ }^{140}$ interest in deterring its citizens from engaging in piracy off its Coast, its inability to curb such piratical attacks gives other States like Kenya room to argue in favor of exercising jurisdiction to prescribe over such conduct. ${ }^{141}$ This appears to be what Kenya has done with the passage of the Merchant Shipping Act.

Kenyan courts have held that Kenyan law ought not to be interpreted as to violate international law. ${ }^{142}$ Kenya's new

http://www.turkishweekly.net/print.asp?type=1\&id=63755.

137. RESTATEMENT (THIRD) OF FOREIGN RELATIONS LAW \& $403 \mathrm{n} .8$ (1987).

138. Rio Tinto Zinc Corp. v. Westinghouse Elec. Corp., [1978] A.C. 547, 616 (H.L.) (U.K.) (holding that the 'exercise by the United States courts of extraterritorial jurisdiction in penal matters in the view of Her Majesty's Government is prejudicial to the sovereignty of the United Kingdom); see also RESTATEMENT (THIRD) OF FOREIGN RELATIONS LAW § 403(1) (1987). ("[A] state may not exercise jurisdiction to prescribe law with respect to a person or activity having connections with another state when the exercise of such jurisdiction is unreasonable.").

139. See, e.g., United States v. Nippon Paper Indus. Co., 109 F.3d 1, 8 (1st Cir. 1997), cert. denied, 523 U.S. 1044 (1998) ("[W]e see no tenable reason why principles of comity should shield NPI [a Japanese entity] from prosecution. We live in an age of international commerce, where decisions reached in one corner of the world can reverberate around the globe in less time than it takes to tell the tale. Thus, a ruling in NPI's favor would create perverse incentives for those who would use nefarious means to influence markets in the United States, rewarding them for erecting as many territorial firewalls as possible between cause and effect."). But see id. at 10 (Lynch, J., concurring) ("In this criminal case, it is our responsibility to ensure the executive's interpretation of the Sherman Act does not conflict with legal principles, including principles of international law.").

140. See RESTATEMENT (THIRD) OF FOREIGN Relations LAW \& 403(3) (1987) ("When it would not be unreasonable for each of two states to exercise jurisdiction over a person or activity ... a state should defer to the other state if that state's interest is clearly greater.").

141. See William Reno, Shadow States and the Political Economy of Civil Wars, in GReEd AND GRIEVANCE: ECONOMIC AGENDAS IN CIVIL WARS 43 (Mats Berdal \& David M. Malone eds., 2000) (explaining that States like Somalia are the "product of personal rule, usually constructed behind the facade of de jure state sovereignty").

142. R.M. v. Attorney Gen., [2006] eKLR 27 (Kenya), available at http://www.kenyalaw.org/CaseSearch/case_download.php?go $=62792276441650128565711$ 
extraterritorial piracy law must be examined to see if it is prejudicial to Somalia, a State with no effective control over its territory or its maritime jurisdiction. This is a primary reason why Somalia is used as a launching pad for piratical attacks. The Security Council has encouraged all States and "in particular flag, port and coastal States, States of the nationality of victims and perpetrators of piracy and armed robbery, and other States with relevant jurisdiction under international law and national legislation," to cooperate in both the investigation and prosecution of those responsible for piratical acts and robbery on the high seas. ${ }^{143}$ Seen in this light, the Merchant Shipping Act could very well illustrate the authority States have now been granted by the Security Council's legislative mandate in prescribing rules of conduct and engagement in dealing with piracy.

Somalia's juridical statehood, however, is not in question. ${ }^{144}$ It is represented in international bodies like the United Nations, ${ }^{145}$ and recently contributed a judge to the International Court of Justice. ${ }^{146}$ Nevertheless, because of Somalia's lack of effective control, a variety of private actors emerged to command the lucrative gateways to foreign markets from the port cities of Kismayo and Mogadishu. ${ }^{147}$ The emergence of piratical attacks from these Somali cities is further evidence of the loss of their

\&link $=$.

143. S.C. Res. 1816, Il 11, U.N. Doc. S/RES/1816 (June 2, 2008).

144. See S.C. Res. 1853, Preamble, U.N. Doc. S/RES/1853 (Dec. 19, 2008) (reaffirming "the importance of the sovereignty, territorial integrity, political independence and unity of Somalia").

145. Reno, supra note 141 , at 45 ("Nearly all governments recognize shadow states as interlocutors in global society and conform to the practice of extending sovereignty by right to former colonies. This principle applies in cases where formal state capacity is practically nil. For example, Somalia holds a seat in the United Nations, exists as an entry in World Bank tables, and presumably has access to foreign aid, provided an organization there can convince outsiders that is the rightful heir to Somalia's existing sovereignty .... Jackson observed that this leads to external support for de jure sovereignty of states with very weak internal administrations, relieving rulers of the need to strengthen institutions to protect productive groups in society, from which regimes could extract income."); see also PAul COllier, THE BotTOM BILlion: WHY THE POOREST COUNTRIES ARE FaIling AND What CAN BE DONE ABout IT 4 (2007) (noting that Somalia is "represented" in the international arena).

146. See Press Release, International Court of Justice, United Nations General Assembly and Security Council Elect Five Members of the Court (Nov. 7, 2008), available at http://www.icj-cij.org/presscom/files/3/14863.pdf. The elected Somalia national was Judge Abdulqawi Ahmed Yusuf. He officially joined the Court on February 6, 2009. Id.

147. See generally PETER D. LITTLE, SOMALIA: ECONOMY WITHOUT STATE 83-122 (2003) (exploring Somalia's "resilient" economy despite war, droughts, and famine). 
commercial significance and the threat posed to global commerce in a major lane of maritime transport in the world. ${ }^{148}$ Markets of violence ${ }^{149}$ such as for piratical attacks on the high seas, evidence the uphill challenges that confront the Transitional Federal Government of Somalia to consolidate itself into an effective government. If the people of Somalia and their interests in building effective structures of governance and addressing the problems that drive some of them to engage in piracy is the rightful concern of the international community, a comity concern arises. ${ }^{150}$ Indeed, the Transitional Government of Somalia's representative in the Security Council noted that supporting Somalia's engagement in a comprehensive peace process should not be sidelined by efforts to address piracy.

Effective regional and international efforts should be redoubled, including the Djibouti Peace Process ${ }^{152}$ under the auspices of the Inter-Governmental Association on Development (IGAD) and the African Union Mission in Somalia (ANISOM), ${ }^{153}$

148. The Suez Canal, which links the Red Sea to the Indian Ocean off the Gulf of Aden, is one of the most important shipping lanes in the world. 11 THE NEW ENCYCLOPÆDIA BRITANNICA 353 (15th ed. 1988). It reduced sea journeys through the Cape of Good Hope off the Southern Coast of Africa with its reopening in 1975. Id. Somalia's nationalist ambitions in the horn of Africa in the 1970s threatened the importance of this corridor of commerce. See Abdi Sheik-Abdi, Somali Nationalism: Its Origins and Future, 15 J. MOD. AFR. STUD. 657, 661-665 (1977).

149. See Reno, supra note 141 , at 44.

150. See Ruth Gordon, Saving Failed States: Sometimes a Neocolonialist Notion, 12 AM. U. J. INT'L L. \& POL'Y 903, 971-974 (1997) (arguing in favor of a people-centered approach as a way of rethinking the failed states paradigm).

151. See Press Release, United Nations Security Council, Security Council Expresses Intention to Establish Peacekeeping Mission in Somalia (Jan. 16, 2009), available at http://www.un.org/News/Press/docs/2009/sc9574.doc.htm (reporting the views of Elmi Ahmed Duale of Somalia to the effect, "if the international community placed the acknowledged priority of a comprehensive peace on the ground ahead of its efforts to help the Somali Government promote and ensure stability and political progress in the meantime, 'it might take another 10 years'"); see also infra Part VI.

152. See generally Djibouti Peace Process - Djibouti Agreement, http://www.unsomalia.org/Djibouti_Peace_Process/index.asp.

153. See Inter-Governmental Authority on Development (IGAD), Communique of the 31st.Extra-Ordinary Session of the IGAD Council of Ministers, (Dec. 22, 2008), available at http://www.igad.org/index.php?option=com_content\&task=view\&id=206 (noting and reiterating IGAD's position that "the escalation of acts of piracy along Somali waters is a symptom of the overall economic, political, security and social problem afflicting Somalia in the last 18 years, and that sustainable solution can only be achieved through addressing the root causes, in particular through the establishment of institutions of governance and protection of the people of Somalia"); see also S.C. Res. 1853, supra note 144, Preamble (noting the importance of this mission). This resolution also lists several other initiatives established to conduct a variety of activities relating to the 
so that efforts to end piracy are not undertaken in isolation of the larger crisis in Somalia. Kenya has been at the forefront in supporting the Transitional Federal Government of Somalia, as well as in combating piracy off its coast. ${ }^{154}$ While Kenya has security concerns arising from its shared border with Somalia ${ }^{15 .}$ and has even returned Somali refugees across the border, ${ }^{156}$ it would be implausible to argue that the Kenyan government does not believe comity concerns may arise from the manner in which it conducts its relations to Somalia. ${ }^{157}$ Kenya must implement its new

restoration of peace and stability in Somalia. Additionally, there is an International Contact Group on Somalia that includes Somalia's development partners in the EU and elsewhere. Norway Chairs the International Somalia Contact Group, Norway - Mission to the UN, http://www.norway-un.org/News/Archive+2006/20060615_somalia.htm. The UN Secretary General has also appointed a UN Special Representative of the Secretary General for Somalia. Secretary-General Appoints Ahmedou Ould-Abdallah of Mauritania as Special Representative for Somalia, United Nations, http://www.un.org/News/Press/docs/2007/sga1095.doc.htm.

154. NANCY KARIGITHU, KENYA MARITIME AUTHORITY, ROLE PLAYED BY KeNYA IN THE FIGHT AGAINST PIRACY AND ARMED ROBBERY AGAINST SHIPS IN WATERS OFF THE COAST OF SOMALIA, http://www.un.org/Depts/los/consultative_process/documents/ 9_nancykarigithuabstract.pdf. In November 2005, Kenya pledged to increase naval patrols to combat piracy off the Indian Ocean coast. In September of that year, the country had acquired a new high-speed boat for that purpose. In February 2006, Kenya entered into a joint Communique with Tanzania, Mozambique, and the Transitional Federal Government of Somalia on Acts of Piracy and Armed Sea Robbery. Under this agreement, these countries agreed to establish a Joint Task Force to conduct anti-piracy controls and to establish collective reporting of piratical incidents. Id.

155. See generally Ken MENKHAUS, U.S. AgENCY FOR InT'L DEV., KENYA-SOMALIA BORDER CONFLICT ANALYSIS (2005) (analyzing the chronic instability along the KenyaSomalia border zone). Kenya has had a troubled history with Somalia from the Somalia/Kenya war of 1964 that was settled in the Arusha Accords of 1967. See Org. of African Unity (OAU), Resolutions and Declarations Adopted by the Fourth Ordinary Session of the Assembly of Heads of State and Gov't Held in Kinshasa, Congo, From 11 to 14 Sep. 1967, AHG/Res. 49 (IV) (discussing the 1964 war in which a Somali irredentist movement claimed part of Kenyan territory for Somalia). The rise of radical Islamist movements in the 1990s, large flows of Somalia refugees to Kenya as well as flows of arms, and cross border raids including cattle rustling resulted in rising insecurity in Northern Kenya and continued border tensions. MENKHAUS, supra, at ii-iii.

156. HuMAN RIGHTS WATCH, FROM HORROR TO HOPELESSNESS: KENYA'S ForgotTEN SOMALI REFUGEE CRISIS 1 (2009) (documenting dozens of cases of forced return of Somali asylum seekers and refugees from the border areas).

157. See Kenya Ministry of Foreign Affairs, Foreign Policy, http://www.mfa.go.ke/mfacms/index.php?option=com_content\&task=view\&id=13\&Itemid $=31$ \&limit $=1$ \&limitstart $=2$ (last visited July 14,2009 ) (stating that the country is committed to "[t]he desire to promote economic development [that] will influence Kenya's approach to foreign policy while maintaining its traditional core principles and norms of non-alignment, non-interference in internal affairs of other states, good neighborliness, peaceful settlement of disputes and adherence to the charters of the UN and African Union"). 
extraterritorial authority over non-nationals carefully in light of the unlikely reciprocal comity consequence that Somalia would hale Kenyans with little contact to Somalia into Somali courts for conduct arising entirely on the high seas. ${ }^{158}$ Such care is not unwarranted given recent Security Council resolutions allowing third States to pursue pirates within Somalia's territorial waters, ${ }^{159}$ and another resolution effectively permitting such States to engage in a land pursuit. ${ }^{160}$ What is more, there are suggestions of establishing an internationally administered coast guard for Somalia, ${ }^{161}$ which may ultimately be regarded as an occupying force and produce a similar reaction as that to U.S. forces in Somalia in the early 1990s. ${ }^{162}$ The last time the Security Council

158. A very aggressive implementation of this new extraterritorial law would constitute a kind of 'legal imperialism' that would fall short of balancing Kenya's legitimate interests in safe passage of maritime commerce. For an analogous case of such skepticism in relation to Texas' extension of personal jurisdiction over conduct occurring entirely within Mexico, see Transportadora Egoba v. Arrendondo, 217 S.W.3d 603, 28 (Tex. App. 2006), cert. denied, 128 S. Ct. 810 (2007) (noting "[f]or more than a century, the United States has rejected Mexican attempts to assert extraterritorial judicial jurisdiction over Americans who have allegedly wronged Mexican citizens in the United States ... . If the United States expects this deference from Mexican courts, then United States courts should exercise reciprocal restraint. The attempt to exercise jurisdiction over a foreign defendant in this case, based solely on foreign conduct, is precisely the type of 'legal imperialism' that this court has recently cautioned courts to avoid and that runs afoul of comity and other international law norms, provoking undesired consequences for American interests.").

159. See S.C. Res. 1816, supra note 143, If 7 (permitting, for a six month period, States cooperating with Somalia's Transitional Federal Government to enter into Somalia's territorial waters and use "all necessary means to repress acts of piracy and armed robbery" at sea). This authority was renewed for a twelve month period by S.C. Res. 1846, If 10, U.N. Doc. S/RES/1846 (Dec. 2, 2008).

160. See S.C. Res. 1851, II 6, U.N. Doc. S/RES/1851 (Dec. 16, 2008) (authorizing third Statess to undertake "all necessary measures" to interdict those using Somali territory to plan, facilitate, or undertake piracy and armed robbery off the Somalia Coast with the prior notification of Somalia's Transitional Federal Government); see also S.C. Res. 1816, supra note 143, If 10 (authorizing States and International Organizations to use all necessary means within Somalia's territorial waters efforts to combat piracy and robbery in the high seas and noting that such authorization was procured with the consent of the Transitional Federal Government of Somalia). The authorizations here run for a period of 12 months from December 16, 2008.

161. See Roger Middleton, Piracy in Somalia 10 (Chatham House Briefing Paper, AFP BP $08 / 02$, Oct. 2008) (suggesting "an internationally sanctioned and administered coast guard for Somalia").

162. See John H. Cushman, Jr., 5 G.I.'s Are Killed as Somalis Down 2 U.S. Helicopters, N.Y. TIMES, Oct. 4, 1993, at A1. The goal of the American forces in Somalia was to capture General Mohammed Farah Aideed. The failure to capture Aideed and the October 3, 1993 downing of two U.S. helicopters resulted in criticisms of the Clinton Administration in Congress. President Clinton thereafter announced a pull out of 
authorized the use of "all necessary means" with respect to Somalia, it turned out to be a major turning point in committing UN forces to peace making, in Somalia in particular, and Africa in general. ${ }^{163}$ The failure of United Nations Operation In Somalia (UNISOM I and II) of the 1990s can be accounted for in part because UNISOM erroneously maintained "[t]he illusion that where people are dying in large numbers because of civilian conflict there can be a type of intervention that does not immediately interfere with the domestic politics of a country and include a 'nation-building' component." ${ }^{164}$ Thus, although piracy must be dealt with to protect the interests of safe maritime commerce, authorizing the most intrusive use of force on Somali territory and territorial waters without a concomitant commitment to rebuilding the Somali state is to repeat the mistakes of the 1990s, with no promise of ultimately ending piracy.

\section{CONCERNS OF INTERNATIONAL HUMANITARIAN LAW}

The Security Council has called upon States engaged in the capture, investigation, and prosecution of piracy to ensure that their conduct is "consistent with applicable international law including international human rights law." ${ }^{165}$ In addition, in Resolution 1851 of December 16, 2008, the Security Council urged these anti-piracy efforts to be "undertaken consistent with applicable international humanitarian and human rights law." 166

These Security Council decisions for the observance of international law in the conduct of anti-piracy efforts are crucial, particularly given that the council has authorized the use of "all necessary means,". including in Somali territory and territorial waters, as discussed above. ${ }^{167}$ There is an increasing and unprecedented naval presence off the Indian Ocean Coast. The

American troops, which in turn resulted in major pullbacks of UNISOM troop contributions from other countries. Paul F. Horvitz, Fending Off Congress, Clinton Links Pullout to Safety for Somalis, INT'L HeRALD TRIBUNE, Oct. 7, 1993, at 1.

163. See John A. DRYSDALE, What EVER HAPPENED to Somalia? 188-214 (2001) (discussing in detail how hastily passed resolutions by the Security Council authorizing the use of force ended disastrously).

164. Walter Clarke \& Jeffrey Herbst, Somalia and the Future of Humanitarian Intervention, in LEARNING FROM SOMALIA: THE LESSONS OF HUMANITARIAN INTERVENTION 245 (Walter Clarke \& Jeffrey Herbst, eds., 1997).

165. S.C. Res. 1816, supra note 143, II 11.

166. S.C. Res. 1851, supra note $160, \mathbb{9} 6$.

167. Supra Part VI. . 
countries involved include Russia, France, Norway, Great Britain, Turkey, Germany, India, China, South Korea, Iran, Canada, Malaysia, United States, and Kenya, among others. ${ }^{168}$ In November 2008, the EU announced its first-ever naval missioncombating piracy off the Coast of Somalia. ${ }^{169}$ The British Navy leads this EU force. ${ }^{170}$ On its part, the United States established a new multinational task force, Combined Task Force 151, which created the Maritime Security Patrol Area in the Gulf of Aden in August 2008 to conduct counter-piracy missions. ${ }^{171}$ India has argued in favor of a UN-authorized force in place of this patchwork of U.S.-allied and EU forces. ${ }^{1}$

In early December 2008, France reported having already arrested twelve pirates, ${ }^{173}$ but has yet to bring formal charges in court. Indeed, there are reports of many other arrests of suspected pirates, but much fewer accounts of their release or of charges being brought against them. ${ }^{174}$ Thus, this huge militarization in

168. James Kraska \& Brian Wilson, Fighting Pirates: The Pen and the Sword, 25 WORLD POL'Y J. 41, 42 (2008); KARIGITHU, supra note 154 at 1; Middleton, supra note 161.

169. Council Decision (EC), No. 2008/918/CFSP of Dec. 8, 2008, Launch of a European Union Military Operation to Contribute to the Deterrence, Prevention, and Repression of Acts of Piracy and Armed Robbery off the Somali Coast, art. 1, 2008, O.J. (L 330) 19; Council Joint Action 2008/749/CFSP, European Union Military Coordination Action in Support of U.N. Security Council Resolution 1816, art. 1, 2008 O.J. (L 252) 39 (NAVCO); Council Joint Action 2008/851/CFSP, European Union Military Operation to Contribute to the Deterrence, Prevention and Repression of Acts of Piracy and Armed Robbery off the Somali Coast, art. 1, 2008 O.J. (L 301) 33 (EC); EU Launches Anti-Piracy Mission Off Somalia, AFP, Nov. 11, 2008, available at http://www.eubusiness.com/newseu/1226331124.09.

170. EU Launches Anti-Piracy Mission Off Somalia, supra note 169.

171. Multinational Task Force Targets Pirates, AMERICAN FORCES PRESS SERVICE, Jan. 8, 2009, http://www.defenselink.mil/news/newsarticle.aspx?id=52586; STATEMENT OF VICE ADMIRAL WILlIAM E. GORTNEY, U.S. NAVY COMMANDER, U.S. NAVAL FORCES CENTRAL COMMAND Before tHe HOUSE ARMEd SERvices COMMITTEe ON COUNTER-Piracy Operations in the U.S. CEnTral COMmand AREA OF OPERATIONS 12 (Mar. $5, \quad$ 2009) available at http://armedservices.house.gov/pdfs/FC030509/Gortney_Testimony030509.pdf [hereinafter STATEMENT OF VICE ADMIRAL GORTNEY].

172. See Kalyan Ray, SOS: Operation Success, Prosecution Dilemma, DECCAN HERALD, Dec., 21, 2008,

available at $\mathrm{http}: / / \mathrm{www}$.decannherald.com/Content/Dec2112008/panorama1220107900.asp.

173. Security Council Adopts Resolution on Piracy in Somalia, United Nations Radio broadcast (Feb. 12, 2008) (transcript available at http://www.unmultimedia.org/radio/engligh/printy/64056.html).

174. On March 5, 2009, the U.S. military reported that the combined naval forces off the Coast of Somalia had encountered and disarmed approximately 250 pirates; 130 of them had been released, 110 turned over for prosecution, and 7 were "pending final 
combating piracy is likely to create large numbers of suspected pirates held in undisclosed locations, at variance with their rights to process under international law. Some reports state that the mission of the Combined Maritime Forces off the Coast of Somalia is to "disrupt and deter" rather than to capture and hold these suspects accountable. ${ }^{175}$ Even if this is the mandate of the forces off the Coast of Somalia, the importance of having regard for international humanitarian law in the disruption and deterrence of piratical acts remains crucial. For example, the capture of the suspects now on trial in the Netherlands was procured by firing flares at their vessel, which subsequently caught fire. The Danish Navy was able to rescue the suspects before they drowned. ${ }^{176}$ While this incident ended relatively well, it highlights the importance of conforming to international humanitarian law. The late March 2010 killing of a Somali piracy suspect by armed private security guards on board a commercial shipping vessel further vindicates the need to question the further escalation of military force off the coast of Somalia. ${ }^{177}$

\section{Concerns of Prosecuting Piracy in the Kenyan JUDICIARY}

There are legitimate concerns about the independence, congestion, and corruption ${ }^{178}$ of the Kenyan judiciary. These

disposition.”. STATEMENT OF VICE ADMIRAL GORTNEY, supra note 171. In early March 2009 , the U.S. Navy released nine suspected pirates and handed them over to the authorities of the Puntland Coast Guard after no evidence against them was uncovered. See Navy Releases 9 Suspected Pirates, Citing Lack of Evidence, CNN, Mar. 2, 2009, available at http:/www.cnn.com/2009/US/03/02/somalia.pirates/index.html.

175. Jim Garamone, New Central Command Unit Makes It Tough to be a Pirate, AMERICAN FORCES PRESS SERVICE, Jan. 15, 2009, http://www.defenselink.mil/News/newsarticle.aspx?id=52704.

176. Pirates Handed Over to Dutch Authorities, The COPENHAGEN POST, Feb 10, 2009, available at http://www.cphpost.dk/news/international/89-international/44705pirates-handed-over-

to-dutch-authorities.html. There are reports that in 2000, the Chinese government executed 13 pirates for robbing a Chinese cargo ship from Hong Kong and for killing 23 sailors on board. See China Executes 13 Pirates, PEOPLE'S DAILY ONLINE, Jan. 29, 2000, available at http://english.peopledaily.com.cn/english/200001/29/eng20000129N103.html.

177. Katharine Houreld, "Private Guards Kill Somali Pirate for the First Time," ASSOCIATED PRESS, March 24, 2010 available at http://www.google.com/hostednews/ap/article/ALeqM5gB7YMEDuCwwY9ncDOtPAkEI 4-H2wD9EL6E700.

178. See generally 1 Report of the Integrity and Anti-Corruption Committee of the Judiciary of Kenya (Ringera Report) (Sept. 2003) (investigating and reporting on the magnitude of corruption in the Kenyan judiciary); see also THE COMMISSION OF INQUIRY 
concerns began shortly after the formation of an independent Kenyan government. ${ }^{179}$ Although the Attorney General is constitutionally empowered to require the Commissioner of Police to investigate any matter that relates to any alleged or suspected offense, ${ }^{180}$ long time Attorney General Amos Wako has often argued that the Commissioner of Police failed to comply with his directives to investigate certain offenses. ${ }^{181}$ The Attorney General and the Commissioner of Police are currently under pressure to resign following a scathing UN Special Rapporteur report of their inability to investigate and prosecute Kenyan police for committing extrajudicial executions. ${ }^{182}$

Thus, there is a sense in which Kenya's agreement to prosecute pirates sits uncomfortably with the challenges facing its investigatory and prosecutorial system at home. These challenges are compounded by "inadequate resources, inadequate remuneration of prosecutors, staff attrition, and placement of the police and the prosecutors under two separate authorities, preventing even the most basic institutional cooperation" in the criminal justice system. ${ }^{183}$ How then can a judicial system facing these challenges, as well as congestion and backlog in the prison system, ${ }^{184}$ take on the task of prosecuting non-national pirates for

INTO THE POST ELECTION VIOLENCE (CIPEV), REPORT OF THE COMMISSION 446 (2008) [hereinafter REPORT OF THE COMMISSION] ("The elements of systemic and institutional deficiencies, corruption, and entrenched negative socio-political culture have, in our view, caused and promoted impunity in this country.").

179. James GathiI, The Dream of Judicial Security of Tenure and THE Reality of Executive InVOlvement In Kenya's Judicial Process 7-8 (Kenya Human Rights Commission, Dec. 1994).

180. CONSTITUTION , Art. 26(4) (2008) (Kenya).

181. See, e.g., REPORT OF THE COMMISSION, supra note 178, at 451.

182. Press Statement, Philip Alston, UN Special Rapporteur UN Special Rapporteur on Extrajudicial, Arbitrary or Summary Executions, Mission to Kenya 16-25 Feb. 2009 (Feb. 25, 2009), available at http://www.unhchr.ch/huricane/huricane.nsf/view01/EAFBE45849510C0EC1257568005348 15?opendocument; see also KENYA NAT'L COMM'N ON HUMAN RIGHTS (KNCHR), REPORT ON EXTRA-JUDICIAL KILLINGS AND DISAPPEARANCES - OVERVIEW OF THE REPORTED AND SAMPLE CASES 2-18 (2007) (highlighting cases of concerted institutional criminal activity within the Kenya police).

183. Michael E. Ranneberger, U.S. Ambassador to Kenya, Speech to the Kenyan Chapter of the International Commission of Jurists (Dec. 8, 2006) (transcript available at http://nairobiembassy.gov/speech_20061208.html).

184. See Mutonya Njuguna, Shimo La Tewa: Life Is a Scene from a Horror Film, DAILY NATION, June 14, 1995 ("the pirates surrendered to Kenya will most likely be held together with others already in custody in the crowded colonial era Shimo La Tewa Maximum Prison where 3,500 prisoners sleep on the floor in humid and sweltering heat and in the most unhygienic conditions"); see also Amnesty Int'l, Kenya-Prisons: Death 
extraterritorial conduct? Perhaps that is why Kenya has declared it will not be a dumping ground for these suspects. Indeed, Kenya must be careful not to become the new offshore center of suspects captured overseas who then languish in the Kenyan legal and prison system for years on end. ${ }^{185}$ Perhaps, for this reason, the United States has assigned Naval Criminal Investigative Service agents and Coast Guard personnel to help in the assembling and deposing of witnesses as well as in pretrial preparatory work to help Kenyan authorities build cases against the pirates.

That being said, the Kenyan judiciary does have experience prosecuting non-nationals. For example, in 2005 the High Court in Mombasa issued a habeas corpus ordering that sixty-three Bangladesh nationals arrested and held in custody with no charges for nine days before being released on bond. ${ }^{187}$ In another case, the Court of Appeals quashed the conviction of a Guinea citizen where his right to the assistance of an interpreter had been violated. ${ }^{188}$ In short, while Kenya's judicial and prosecutorial systems have significant failures, the Constitution and the Courts

Due to Torture And Cruel, Inhuman and Degrading Conditions, AI Index AFR $32 / 010 / 2000$, July 12, 2000, 3 (detailing the conditions in prisons in Kenya). Kenya is running a major donor funded prison reform effort under the Governance, Justice, Law and Order Sector (GJLOS) Reform Programme. See MINISTRY OF JUSTICE AND CONSTITUTIONAL AFFAIRS, GOVERNMENT OF KENYA, MID-TERM REVIEW OF GJLOS REFORM PROGRAMME 5, 50 (2007). Among the agencies involved are the Kenya Prisons Service, the Probation and Aftercare Services and the Office of the Vice President and Ministry of Home Affairs. The Governance Justice Law \& Order Sector (GJLOS) Reform Programme, http://www.gjlos.go.ke/gjinner.asp?cat=agencies (last visited Oct. 30, 2009).

185. See generally HUMAN RIGHTS WATCH, WHY AM I STILL HERE?'THE 2007 HORN OF AFRICA RENDITIONS AND THE FATE OF THOSE STILL MISSING (2008) (explaining and documenting experiences of Kenyans and Somalis illegally arrested, detained, and rendered between Kenya, Somalia, and Ethiopia for extended periods of time).

186. See Jacquelyn S. Porth, Africa: Legal Experts Take Action to Prosecute Pirates, AMERICA.GOV, Feb. 27, 2009, http://useu.usmission.gov/Article.asp?ID=cdf8ebab-84c74531-9b62-629f69c67bde.

187. Ex parte Haque v. Attorney Gen., [2005] eKLR (Kenya), available at http:/www.kenyalaw.org/CaseSearch/case_download.php?go=50227893317769141496115 \&link=e. Suspects arrested in Kenya are required to be charged within twenty-four hours. See Constrtution, Art. 72(3)(b) (2008) (Kenya). If the arrested is suspected of an offense punishable by death, however, he or she must be brought before a court within fourteen days of the arrest or commencement of the detention. Id. For more on this see, James Thuo Gathii, "the Use of Force, Freedom of Commerce and Double Standards in Prosecuting Pirates in Kenya," forthcoming 59 American University Law Review (2010)

188. Djibrilla v. Republic, [2008] eKLR (Kenya), available at http://www.kenyalaw.org/CaseSearch/case_download.php?go=14141816943078946315079 \&link=. 
have built-in protections for criminal defendants. ${ }^{189}$ Even if Kenyan courts worked effectively and efficiently in the prosecution of pirates captured by other States, they would still have to contend with difficult evidentiary questions regarding their captors. For example, in the first such trial in 2006 the suspects alleged that the U.S. Navy tortured them. ${ }^{190}$ Such allegations will certainly taint the outcomes of those trials, furthered by the difficulty in establishing the truthfulness of such allegations due to a lack of independently verifiable evidence. If the suspects are handed over to Kenyan authorities without inordinate delays after their capture, however, medical evidence may perhaps be available. The United Nations Office of Drug and Crime in Nairobi, together with funding from the European Union and other donors, has initiated a four pronged program to assist Kenya to deal effectively with piracy prosecutions. ${ }^{191}$ Such assistance includes working with the police on evidence handling, training prosecutors on international maritime law and equipping them to facilitate prosecutions as well as refurbishing the prisons where the pirates are held to make them more sanitary, while modernizing and improving basic facilities such as sewerage capacity, water supply and other amenities. ${ }^{192}$

\section{CONCLUSION}

Kenya's prosecutions of suspected pirates who are nonnationals that are charged with extraterritorial piratical conduct ought to be limited. I have shown Kenyan courts have adopted an especially expansive understanding of their jurisdiction to prosecute these pirates without addressing the problems posed by the fact that Article 105 of the UNCLOS presupposes jurisdiction primarily belongs to States which actually capture pirates. While

189. Cf. James Gathii, Defining the Relationship Between Corruption and Human Rights 63-81 (Feb. 13, 2009) (working paper, available at http://papers.ssrn.com/sol3/papers.cfm?abstract_id=1342649) (arguing that it is often the rich that work the Constitutional and judicial protections to their advantage when they fall afoul of the law).

190. Suspected Somali Pirate Accuses US of Torture, REUTERS, Aug. 3, 2006, http://www.boston.com/news/world/africa/articles/2006/08/03/suspected_somali_pirate_acc uses_us_of_torture (last visited May 24, 2009).

191. United Nations Office on Drugs, and Crime, UNODC and Piracy, http://www.unodc.org/easternafrica/en/piracy/index.html?ref=menuside (last visited Jan. 25,2010 ).

192. Id. 
Kenya's new Merchant Shipping Act gives Kenyan courts expansive jurisdiction over such suspects, the broad sweep of this new law goes far beyond Kenya's obligations under both the SUA Convention and the UNCLOS, which in their express terms only allow capturing states the right to prosecute. The inability of Somalia to arrest and prosecute such suspects, however, suggests that Kenya may exercise such jurisdiction as part of its contribution to the burden sharing in the prosecution of captured suspects. ${ }^{193}$ In addition, the Kenyan legislation is consistent with the common law norm that crimes defined by international law require domestic law to try or punish them. The Maritime Shipping Act's expansive extraterritorial scope over non-national pirates captured by third States raises important questions about the jurisdiction of subordinate courts as a matter of Kenyan law. The exercise of this new mandate, if exercised by the Kenyan High Court as argued here, suggests that Kenya will have a truly universal jurisdiction statute over piracy upon which piracy prosecutions may be undertaken.

193. The countries neighboring the Malacca and Singapore Straits have cooperated in enhancing the safety, security, and environmental protection of the straits pursuant to Article 42 of the UNCLOS. By analogy, such cooperation among the multinational forces off the Gulf of Aden, for example, the shared prosecution of suspects, may avoid indefinite detentions without trial in violation of international law. 